\title{
Concealable Stigma and Occupational Segregation: Toward a Theory of Gay and Lesbian Occupations
}

Administrative Science Quarterly $1-36$

(C) The Author(s) 2015

Reprints and permissions:

sagepub.com/ journalsPermissions.nav DOI: 10.1177/0001839215576401 asq.sagepub.com

(SAGE

\author{
András Tilcsik, ${ }^{1}$ Michel Anteby, ${ }^{2}$ and \\ Carly R. Knight ${ }^{2}$
}

\begin{abstract}
Numerous scholars have noted the disproportionately high number of gay and lesbian workers in certain occupations, but systematic explanations for this type of occupational segregation remain elusive. Drawing on the literatures on concealable stigma and stigma management, we develop a theoretical framework predicting that gay men and lesbians will concentrate in occupations that provide a high degree of task independence or require a high level of social perceptiveness, or both. Using several distinct measures of sexual orientation, and controlling for potential confounds, such as education, urban location, and regional and demographic differences, we find support for these predictions across two nationally representative surveys in the United States for the period 2008-2010. Gay men are more likely to be in female-majority occupations than are heterosexual men, and lesbians are more represented in male-majority occupations than are heterosexual women, but even after accounting for this tendency, common to both gay men and lesbians is a propensity to concentrate in occupations that provide task independence or require social perceptiveness, or both. This study offers a theory of occupational segregation on the basis of minority sexual orientation and holds implications for the literatures on stigma, occupations, and labor markets.
\end{abstract}

Keywords: occupational segregation, sexual orientation, stigma, gay and lesbian workers, social perceptiveness, task independence

Occupational segregation-the systematic distribution of people across occupations based on demographic characteristics-is a pervasive and consequential phenomenon in contemporary organizations. The concentration of members of a demographic group, such as women or racial minorities, in certain occupations profoundly shapes individuals' social and economic prospects

${ }^{1}$ Rotman School of Management, University of Toronto

2 Harvard University 
(England, Chassie, and McCormack, 1982; Reskin, 1993; Mandel, 2013). Likewise, occupational segregation has important consequences for organizations, such as narrowing the talent pools from which employers might hire and shaping the demographic profile of different positions and professional groups within organizations (Dobbin et al., 1993; Kalev, Dobbin, and Kelly, 2006;

Barbulescu and Bidwell, 2013; Bidwell et al., 2013).

The occupational segregation of gay and lesbian workers-"one of the largest, but least studied, minority groups in the workforce" (Ragins, 2004: 35)_ presents an unresolved puzzle for researchers. Since the late nineteenth century, numerous scholars have noted the unusually high concentration of gay or lesbian workers in certain occupations (e.g., Ellis, 1897; Baumle, Compton, and Poston, 2009), but systematic explanations for this phenomenon remain elusive. This question is particularly puzzling because, at first glance, these occupations seem to have little in common, ranging from some blue-collar trades (e.g., various repairers and mechanics) to certain service jobs (e.g., flight attendants and massage therapists) and white-collar occupations (such as psychologists and postsecondary teachers).

To date, the most consistent account of this phenomenon has been that lesbian and gay workers are often found in occupations that are traditionally associated with the opposite sex (Baumle, Compton, and Poston, 2009). Although predictions based on this observation account for some of the important patterns in gay and lesbian occupational segregation, they leave a great deal of variance unexplained. Recent U.S. data suggest that nearly half of gay men are actually in occupations in which men are the majority of workers, and twothirds of lesbians work in female-majority occupations. ${ }^{1}$ The tendency of lesbians and gay men to cross occupational gender lines also cannot account for professional fields in which both lesbian and gay workers are overrepresented, such as psychology, counseling, law, and social work (Baumle, Compton, and Poston, 2009). While numerous other explanations have also been proposed for gay and lesbian occupational patterns, many of these apply to just a small set of occupations and are relevant to either gay men or to lesbians (e.g., Bérubé, 1990, 2011; Chauncey, 1994), rather than capturing the drivers of segregation common to both populations.

To provide a more comprehensive explanation for lesbian and gay occupational segregation, we conceptualize minority sexual orientation as a potential source of concealable stigma (Smart and Wegner, 1999; Ragins, 2008), that is, a socially stigmatized characteristic that is not readily apparent to observers. We draw on Goffman's (1963) classic insight that a principal challenge for individuals with concealable stigma is to manage information about their stigmatized status in social interactions. This need for stigma management-both at work and beyond-is likely to have important consequences for occupational segregation. In particular, it might lead to an overrepresentation of gay and lesbian workers in occupations that provide a high level of task independence (i.e., freedom to perform one's tasks without substantially depending on others) or require a high level of social perceptiveness (i.e., accurate anticipation and reading of others' reactions), or both.

\footnotetext{
1 Data are from the 2008, 2009, and 2010 American Community Survey (www.census.gov/acs), tabulated by the authors. Gay and lesbian workers were defined as employed individuals living with an unmarried same-sex partner.
} 
Task independence would allow these workers to manage information about their stigmatized status more effectively in the workplace, while also mitigating the risks associated with disclosure. Social perceptiveness is likely to emerge as an important social adaptation or coping skill for many gay and lesbian people at a relatively young age. Addressing the dilemma of disclosure versus concealment across social situations requires sensitivity in order to read and anticipate others' reactions (Radkowsky and Siegel, 1997; Pachankis, 2007), which in turn are valued behaviors in occupations that require social perceptiveness.

We test our predictions with two distinct population samples and multiple measures of sexual orientation. Our first data source is the 2008-2010 American Community Survey (ACS), which provides a nationally representative sample of nearly five million people in the United States and allows us to systematically identify individuals living with a same-sex partner. While the size and quality of this sample offer unique advantages, one limitation is that these data capture only those lesbian and gay workers who are members of a cohabiting same-sex couple. Thus we also test our hypotheses on a second sample, the fourth wave of the U.S. National Longitudinal Study of Adolescent Health, collected in 2008-2009. Although this sample is restricted to respondents between the ages of 26 and 31, it effectively complements the ACS data by providing indicators of sexual orientation independent of partnered status. We combined both samples with data from the Occupational Information Network $(\mathrm{O} * \mathrm{NET})$, the primary source of survey-based information about the characteristics of occupations in the U.S. economy (Liu and Grusky, 2013). These data allow us to test the hypothesis that common to both gay men and lesbians is a propensity to concentrate in occupations that provide task independence or require social perceptiveness, or both.

\section{OCCUPATIONAL SEGREGATION AND CONCEALABLE STIGMA}

Theories explaining occupational segregation typically focus on one of two sides of the labor market equation: the demand side (i.e., employers' needs, preferences, and biases) or the supply side (i.e., workers' preferences, characteristics, and skills) (Kaufman, 2002). On the demand side, employers evaluate job seekers' skills and dispositions to ascertain their fit with certain jobs or work settings. Occupational segregation may therefore be due to employers' selection decisions, reflecting either accurate assessments of human capital or stereotypes about what constitutes a "proper" match for the occupation, the latter of which may result in discrimination against those deemed unsuited for the position (Reskin and Roos, 1987; see also Fernandez-Mateo and King, 2011). Thus employment discrimination and a desire to keep certain people out of certain kinds of jobs-for instance, African Americans from jobs involving frequent contact with customers (Pager, Western, and Bonikowski, 2009) or women from managerial positions (Kanter, 1977) — can contribute to occupational segregation.

From a supply-side perspective, research in vocational psychology has focused on factors that affect career choices. A recurring idea in this literature is that people with similar behavioral dispositions and skills are drawn to similar occupational and employment settings in a process that involves a matching of self and occupation (Kidd, 1984; Holland, 1997; Hansen and Dik, 2004). This 
matching process implies that "people who are more comfortable with and are better skilled in employing a [given set of behaviors] are likely to be drawn to occupations in which engagement in such behaviors is instrumental to task accomplishment" (Stern and Westphal, 2010: 286). Broader cultural perspectives on occupational segregation have provided some insight into the sources of the characteristics and preferences of workers that underlie this matching process (England et al., 1994; Budig and England, 2001). This work suggests that internalized beliefs about group differences shape individuals' occupational aspirations from a young age (Xie and Shauman, 1997; Bourdieu, 2001), thus influencing educational and career decisions throughout the life course (Kanter, 1977; Blair-Loy, 2001; Fernandez and Friedrich, 2011). At the same time, while much research explores mechanisms of occupational segregation due to visible characteristics, particularly gender and race, few theoretical explanations account for segregation on the basis of stigmatized but potentially concealable characteristics. This lacuna is particularly striking in the case of gay and lesbian workers.

\section{The Puzzling Segregation of Gay and Lesbian Workers}

Scholars have long noted the existence of gay and lesbian occupational "ghettos" and distinctively "queer work" (Bérubé, 2011). As Hewitt (1995: 465) pointed out, "gay men have a very distinctive occupational profile, and ... the differences between gay men and the general male population are at least as great as those between men and women." One of the first scholars to observe this phenomenon, Havelock Ellis (1897: 294), noted that gay men were drawn to "certain avocations," including literature, medicine, acting, and hairdressing. Ellis (1897: 296) argued that the dramatic and artistic "aptitudes" of gay men (evidenced by the presumed overrepresentation in literature and acting) were "due to the circumstances of [a gay man's] life, which render him necessarily an actor-and in some few cases lead[ing] him into a love of deception." Also, Ellis (1897: 294) explained the concentration of gay men in hairdressing and medicine by the supposedly desirable "close physical association" that barbers and physicians have with their clients and patients. In retrospect, these explanations seem far-fetched, but they do capture a recurring puzzle about the distinctive occupational profile of gay and lesbian workers.

Contemporary scholars have noted the strikingly high concentration of lesbian and gay workers in a range of occupations, from blue-collar craft workers and commercial truck drivers to army mechanics and gymnastic teachers for lesbians, and from professional dancers and church organists to sailors and interior designers for gay men (Whitam, 1986; Hetherington and Orzek, 1989; Bérubé, 1990; Chauncey, 1994; Bailey and Oberschneider, 1997; Blandford, 2003). But many existing explanations for occupational segregation by sexual orientation are either largely speculative or limited to a small set of occupations. Although some scholars, for example, have invoked the supposed "gay friendliness" of certain occupations to explain segregation patterns (Harry and DeVall, 1978; Berger, 1982; Hewitt, 1995), such explanations risk being tautological because they often define "gay-friendly" occupations as those with a high proportion of gay men. Moreover, though the notion that "gays often tend to hire other gays as employees" (Harry and DeVall, 1978: 160) might help explain why an occupation continues to have a high concentration of gay workers, it 
does not explain more generally why some occupations have such high concentrations in the first place while others do not.

Other scholars have suggested that gay and lesbian workers might be commonly found in highly gender-segregated occupations, with gay men gravitating toward mostly all-male settings like navy ships, lumber camps, and cattle ranches (Chauncey, 1994: 91) and lesbians often working in all-female settings, like the Women's Auxiliary Army Corps during World War II (Bérubé, 1990: 28). Systematic evidence from large-scale datasets, however, clearly contradicts this view, showing that both gay men and lesbians often work in genderbalanced occupations or occupations in which they are a gender minority (Baumle, Compton, and Poston, 2009). Still other accounts of segregation are based on ad hoc explanations that apply to one particular occupation but not to the majority of occupations. For example, some observers linked the overrepresentation of gay men among cruise ship stewards to the U.S. military's discrimination against gay men, because many discharged gay service members subsequently found new jobs with cruise ships operators (Bérubé, 2011). Although such explanations may be appealing in the context of a particular occupation, they do not explain wider segregation patterns.

To provide a broader explanation for the puzzle of lesbian and gay occupational segregation, some scholars have offered a sex-typing perspective. Sextyping arguments suggest that lesbians and gay men will be overrepresented in certain occupations because they prefer to cross gender lines in their working lives and join occupations that are traditionally associated with the opposite sex or, in the case of gay men, because they are more willing than heterosexual men to cross gender lines and engage in stigmatized "women's work." This lens builds on a gendered view of occupations that divides work into traditionally female- or male-type work (Williams, 1995). In this view, lesbians might be more inclined than heterosexual women to engage, for example, in (typically male) police work (Martin, 1980) and blue-collar trades (Allegra, 1996).

Similarly, gay men might gravitate toward stereotypically female work, including commercial airline steward jobs (Hochschild, 1983), nursing (Williams, 1992), and front-desk hospitality jobs (Sherman, 2007: 304). ${ }^{2}$

One of the first studies to report national estimates of gay and lesbian occupational segregation used U.S. Census data for same-sex partners in 33 of the largest professions, which provided some support for the sex-typing hypothesis, showing that gay men and lesbians were more likely to cross occupational gender boundaries (Baumle, Compton, and Poston, 2009). At the same time, sex-typing arguments did not explain the key finding that both gay and lesbian workers were "concentrated in fields that are focused on creativity, psychology/counseling, and law/social work" (Baumle, Compton, and Poston, 2009: 13). Thus, although this perspective explains some variation, it does not fully account for the underlying factors that drive segregation on the basis of sexual orientation.

\footnotetext{
${ }^{2}$ An alternative perspective that leads to the same basic prediction is that, because male incomes tend to be higher than female incomes, gay men-who expect to have a partner with a male income-are more willing to select occupations with relatively low wages (i.e., female-dominated occupations), while the opposite is true for lesbians. See, for example, Kyei and Madden (2013).
} 


\section{Concealable Stigma and Occupational Segregation}

Though much research has explored occupational segregation on the basis of visible characteristics, segregation due to concealable stigma is likely to operate in fundamentally different ways. One major difference is that direct exclusion, such as employment discrimination at the point of hire, likely plays a much more straightforward role in segregation on the basis of visible characteristics: employers can readily observe such characteristics and might discriminate on that basis against a group of job seekers, reducing their access to certain occupations. But, of course, this mechanism cannot explain segregation if employers cannot observe the characteristic in question. For example, even though a large proportion of survey respondents express discomfort over the possibility of having a gay or lesbian person as their doctor or their child's teacher (Powell et al., 2010: 66), in reality it may be quite difficult to systematically identify and avoid lesbian and gay doctors or teachers. Moreover, even in field experiments in which fictitious lesbian and gay job seekers do reveal information indicating their sexual orientation, there is little systematic variation across occupations in the level of discrimination (e.g., Drydakis, 2009; Tilcsik, 2011), which suggests that variation in employers' propensity to discriminate is not the primary driver of segregation. Thus, although discrimination may be at play in generating segregation on the basis of sexual orientation, a large part of its influence is likely to occur through more indirect mechanisms.

To unpack these mechanisms, we build on Goffman's (1963) classic insights into the distinct nature of visible versus concealable stigma (see Ragins, 2008). According to Goffman, the principal challenge for a person with a concealable stigma is the management of information in social interactions about the stigma: "To display or not to display; to tell or not to tell; to let on or not to let on; to lie or not to lie; and in each case, to whom, how, when, and where" (Goffman, 1963: 42). As recent research shows, individuals with a concealable stigma continually face a dilemma of disclosure, which forces them to regularly interpret ambiguous social situations and adapt to the threat of potential discovery (Croteau, 1996; Reimann, 2001; Pachankis, 2007; Connell, 2015).

This need for stigma management may have powerful consequences for occupational segregation. We develop this argument in two steps: we first focus on the management of stigma-related information in the workplace and then consider this information management process in everyday social interactions from an early age onward. First, given the dilemma of disclosure in the workplace, gay men and lesbians are likely to place especially great value on task independence at work, to be able to perform their tasks without substantially depending on coworkers and supervisors. Task independence allows lesbian and gay workers to manage information about their stigmatized status more effectively and may also reduce the risks associated with disclosure in the workplace. Second, given the need to manage information about concealable stigma in everyday social interactions, gay and lesbian workers will be likely to be concentrated in occupations in which social perceptivenessaccurately anticipating and reading others' intentions and reactions-is essential for job performance. Forced to manage information about a stigmatized attribute on a daily basis from an early age, many gay men and lesbians seem to adapt to their stigmatized role by developing an increased sensitivity and diagnostic accuracy with regard to others' reactions (Anderson and Randlet, 
1993; Sedlovskaya et al., 2013; Knight, Tilcsik, and Anteby, 2014), a valuable ability in occupations that require a high degree of social perceptiveness. Thus we expect gay and lesbian workers to be overrepresented in occupations that provide a high level of task independence or require a high level of social perceptiveness, or both.

\section{Task Independence and Occupational Segregation}

For lesbian and gay workers, the decision of whether to reveal their sexual orientation in the workplace, combined with the fear that revelation might occur against their will, is often described as "the most difficult career challenge" and an "ongoing process that occurs with each interaction" in the workplace (Ragins, Singh, and Cornwell, 2007: 1103, 1105). This is understandable, as disclosure of minority sexual orientation at work has been shown to lead to discrimination, termination, and even physical threats (D'Augelli and Grossman, 2001; Ragins and Cornwell, 2001). Moreover, fear of the consequences of disclosure has a profound and often detrimental effect on the work experiences of many gay men and lesbians (Ragins, 2004; Drydakis, 2015). Unsurprisingly, one study, based on interviews with 70 gay men working in corporate jobs in the United States, found that every single participant had posed as heterosexual at some point to avoid discrimination at work (Woods, 1994). Similarly, other studies suggest that a high proportion of lesbians do not disclose their sexual orientation to employers (Fassinger, 1995; Ragins, 2004). Further complicating the situation is the fact that many gay and lesbian workers who want to disclose their sexual orientation prefer to do so selectively, hoping to confide in some but not all coworkers and supervisors (Croteau, 1996; Lance, Anderson, and Croteau, 2010).

As a result, the threat of discrimination and the need to manage information about one's stigmatized status are important factors shaping the career choices of lesbian and gay workers (Baumle, Compton, and Poston, 2009). In particular, these workers might avoid occupations in which concealment or selective disclosure is difficult and penalties for a revealed minority sexual orientation are potentially high (Escoffier, 1975; Badgett and King, 1997), sorting instead into occupations in which concealment or selective disclosure is easier and revealing their sexual orientation will have fewer negative repercussions. One broad set of occupations that meet these criteria are those that offer a high degree of task independence at work.

In occupational research, task independence is defined as the degree to which an occupation allows a worker to perform his or her tasks without substantially depending on coworkers or supervisors (Kiggundu, 1981, 1983; Klein, 1991; Peterson et al., 1999). Comparative surveys of workers suggest, for example, that on average massage therapists have a higher level of task independence than construction workers, that taxi drivers report more task independence than food preparation workers, and that social scientists have more task independence than nuclear engineers (National Center for O*NET Development, 2014).

Task independence is distinct from autonomy at work (Kiggundu, 1981; Breaugh, 1985; Klein, 1991), and there is only a modest positive correlation between the two constructs (Kiggundu, 1983). While autonomy is typically defined as discretion over the pace of work and the procedures to be used 
(Hackman and Oldham, 1976), task independence refers to a worker's ability to perform his or her tasks with limited dependence on the work activities of others (Kiggundu, 1981). For example, city bus drivers have limited autonomy because they have little discretion over the pace of their work, their routes, and the driving procedures they follow, but they have a fairly high level of task independence because their task performance does not depend on coworkers or supervisors (Breaugh, 1985). It is also worth noting that task independence need not imply physical separation from other workers (Kiggundu, 1981; Klein, 1991). For instance, call center agents and bank tellers often share an open workspace with their colleagues but perform many tasks independently from one another (National Center for O*NET Development, 2013). Moreover, as these examples illustrate, task independence does not imply a lack of interaction with customers; it refers only to limited dependence on coworkers and supervisors.

Task independence is likely to be particularly important for lesbian and gay workers because they tend to see coworkers and direct supervisors as the most common and consequential source of potential mistreatment and discrimination in the workplace (e.g., Badgett et al., 2007; Badgett and Frank, 2007; HRC, 2009) ${ }^{3}$ In particular, task independence will allow for more control over information about one's stigmatized status and also limit the negative consequences of disclosure. Qualitative research comparing the experience of gay and lesbian workers across different occupations suggests that the concealment or selective disclosure of sexual minority status is likely to be easier in jobs with a high degree of task independence (Ward and Winstanley, 2005). In contrast, when a job involves a high level of dependence on coworkers and supervisors, keeping a stigmatized status a secret, or disclosing it safely to a select few, is likely to be more challenging. Such tightly knit occupational settings-such as firefighting, in which people work closely with one another in highly interdependent teams even when not responding to an emergencymay increase the difficulty of concealment or selective disclosure of private matters. As Ward and Winstanley (2005: 457) argued, when interdependence and the resulting frequent interactions with coworkers are inevitable features of an occupation, it is "harder for people ... to carry on a masquerade of identity." Selective disclosure, in particular, is often difficult in such environments, because information can easily spread beyond the stigmatized individual's control. This is less of a threat, for example, for fire safety inspectors-members of a related occupation who examine buildings and equipment to detect fire hazards-because they work independently from coworkers and supervisors most of the time (National Center for O*NET Development, 2014), and this independence "may mean that it is easier to be in the closet" (Ward and Winstanley, 2005: 457) or to be "out" selectively.

Being in an occupation with task independence can also limit the negative repercussions when one's sexual minority status is (voluntarily or involuntarily) revealed. The consequences of social exclusion and discrimination by

\footnotetext{
3 In contrast, lesbian and gay workers rarely report customers as a source of discrimination or mistreatment (Badgett et al., 2007; Badgett and Frank, 2007; HRC, 2009). This might partially reflect the fact that workers' interactions with customers tend to be more transitory than those with immediate coworkers and direct supervisors. Thus customers are likely to have fewer opportunities to undermine a worker's ability to manage information about his or her sexual orientation and less power to engage in sustained and highly consequential discrimination.
} 
coworkers are likely to be much more severe if the focal individual depends substantially on those coworkers to perform his or her work than when he or she can accomplish work tasks without relying on others. In the former case, because dependence provides coworkers with power over the focal individual (Emerson, 1962), the same degree of ostracism and discrimination can be more damaging for his or her performance and satisfaction at work than in the latter case, when the lack of dependence limits coworkers' power to do harm. For example, fire inspectors or psychologists in private practice can accomplish the primary tasks of their jobs with little or no interference from colleagues who might disapprove of their sexual orientation. In contrast, for sexual minority workers who must perform their work as part of interdependent groups, the disapproval of coworkers can be highly consequential. In such cases, "the costs are higher for coming out because of the dangers of potential negative reactions" (Ward and Winstanley, 2005: 473).

Recent survey results provide support for these ideas. When assessing the importance of different job characteristics, gay and lesbian survey participants in the United States placed significantly greater value on task independence at work than did heterosexual respondents. Relative to heterosexual participants, respondents who described themselves as gay or lesbian indicated a stronger preference for jobs in which they could "work independently from coworkers" and "accomplish tasks without depending too much on other people" (Knight, Tilcsik, and Anteby, 2014: 7). A related result from another recent survey is that lesbian and gay college students were more likely than their heterosexual peers to express a preference for working in their own business $(\mathrm{Ng}$, Schweitzer, and Lyons, 2012).

Because task independence at work makes it easier to conceal or selectively reveal minority sexual orientation and reduces the negative repercussions of disclosure, we expect that gay men and lesbians will be more willing to sort into occupations with higher task independence. This pattern, of course, may be further reinforced over time if task independence leads to a substantial gay or lesbian presence in an occupation and that presence itself subsequently attracts additional lesbian and gay workers, perhaps because of a resulting reputation for tolerance or because lesbian and gay workers in the occupation distribute information about job openings through informal networks to lesbian and gay job seekers. Thus a high degree of task independence can help explain why an occupation becomes segregated in the first place, and this pattern may then be maintained both by continued sorting on the basis of task independence and by second-order (reputation- or network-based) mechanisms. Both directly and indirectly, therefore, a high level of task independence can contribute to a greater proportion of gay and lesbian workers in an occupation. Thus we predict:

Hypothesis $1(\mathrm{H} 1)$ : There is a positive relationship between the level of task independence in an occupation and the proportion of gay and lesbian workers in the occupation.

\section{Social Perceptiveness and Occupational Segregation}

Gay men and lesbians experience the threat of stigmatization not only at work but also in everyday interactions, potentially from an early age onward (Huebner, Rebchook, and Kegeles, 2004; Poteat and Espelage, 2007; McDavitt 
et al., 2008). Whether facing bullying at school or the disapproving eyes of community members, lesbian and gay youth frequently need to navigate potentially unwelcoming terrains (Lipkin, 1999; Pascoe, 2007). This threat, and gay and lesbian individuals' responses to it, may have important consequences for occupational segregation.

Our proposition builds on the notion that individuals who exhibit a given set of dispositions are more likely to select, or be selected into, occupations in which those dispositions are instrumental to task accomplishment (Stern and Westphal, 2010). From a demand-side perspective, employers seeking the best candidates for a position will hire individuals with the skills and characteristics that are most relevant to the job. From a supply-side perspective, individuals might be drawn to occupations in which their skills are most valued (see Padavic and Reskin, 1994) and that involve tasks in which they feel efficacious (Lent, Brown, and Hackett, 1994). For both reasons, workers who have a certain set of skills and characteristics are more likely to be found in occupations in which those skills and characteristics are important for job performance. We suggest that one such characteristic relevant for the segregation of gay and lesbian workers is social perceptiveness, defined as a capacity to anticipate and accurately perceive others' intentions and reactions (Simons, 1966; Gilbert and Kottke, 2009).

The degree to which social perceptiveness is necessary for task accomplishment is a key dimension of an occupation (Peterson et al., 1999; Morgeson, Reider, and Campion, 2005). While social perceptiveness plays a relatively limited role in some occupations (e.g., actuarial analysts and chemical technicians), it is critical in others (e.g., psychologists and teachers), especially those involving frequent interactions with customers, defined broadly to include clients, patients, patrons, students, and others to whom the focal worker provides a service (National Center for O*NET Development, 2014). Thus, in occupational research, social perceptiveness is seen as an individual attribute that plays a role in work performance to different degrees in different occupations. ${ }^{4}$

Existing research indicates that social perceptiveness is likely to be a salient and frequently activated characteristic among gay men and lesbians. Recent survey evidence shows that, compared with heterosexual respondents, gay and lesbian participants reported significantly higher levels of social perceptiveness (sample item: "I can often anticipate others' reactions") (Knight, Tilcsik, and Anteby, 2014). Even after controlling for other demographic factors, such as age, gender, and race, these differences were substantial, with lesbian and gay participants scoring roughly one-half standard deviation above other respondents (Knight, Tilcsik, and Anteby, 2014).

These quantitative findings are consistent with earlier qualitative research on sexual orientation and the management of concealable stigma. The literature on adolescent development suggests that lesbian and gay youths need to develop a high level of social sensitivity and diagnostic accuracy relatively early in life as an adaptation or coping skill in response to the threat of stigmatization

\footnotetext{
${ }^{4}$ Social perceptiveness is related to the construct of self-monitoring (Gilbert and Kottke, 2009), which captures a person's sensitivity and responsiveness to social and interpersonal cues about appropriate behaviors in a situation (Snyder, 1987; Kilduff and Day, 1994; Mehra, Kilduff, and Brass, 2001). But O*NET, the primary source of occupational information in the United States, tracks only the level of social perceptiveness required in a given occupation, not the required degree of selfmonitoring (National Center for O*NET Development, 2014).
} 
(Herdt and Boxer, 1993; Hewitt, 1995; McDavitt et al., 2008). A core conclusion of this research is that many lesbian and gay youths are aware of their status as a sexual minority by early adolescence (American Psychological Association, 1993), and thus "the primary developmental task for homosexually oriented adolescents is adjustment to a socially stigmatized role" (Hetrick and Martin, 1987: 25). In this adjustment process, one of the most important coping mechanisms is to monitor and anticipate the reactions of others to determine when and how to conceal important aspects of one's identity (Martin and Hetrick, 1988; D'Augelli and Hershberger, 1993). Thus careful reading of social cues is a key adaptation for these youths, especially in situations that involve potentially unaccepting individuals whom they can neither avoid nor afford to alienate, such as family members, teachers, and key peers.

As a result, gay and lesbian adolescents tend to develop concealment strategies for a variety of social contexts and relationships and are forced to engage in nearly "constant self-monitoring of that which is automatic for others" (Radkowsky and Siegel, 1997: 195), such that "at a time when heterosexual adolescents are learning how to socialize, young gay people are learning to conceal large areas of their lives from family and friends" (Hetrick and Martin, 1984: 11), a behavior that requires an acute discernment of others' reactions and a heightened sensitivity to social cues in interactions (Radkowsky and Siegel, 1997). Likewise, at school, which is often an environment with "pervasive assumptions, expectations, norms and regulations of compulsory heterosexuality," gay and lesbian students need to "develop . . . social sensitivity [to] skillfully negotiate boundaries and restrictions" (Taulke-Johnson, 2008: 131).

This conclusion also dovetails with the more general observation that the "daily experiences of people with concealable stigmas are often structured by decisions about whether to conceal or disclose" (Sedlovskaya et al., 2013: 697). In making these decisions "individuals with a concealable status may protect themselves by closely attending to social interactions" and by "monitoring the actions and discerning the potential perspectives of interaction partners" (Pachankis, 2007: 333). Related research suggests that individuals can combat the negative stereotypes that their peers may have of them through heightened sensitivity and responsiveness to social cues about behavioral expectations (Flynn, Chatman, and Spataro, 2001). In a similar way, sensitivity to others' reactions and accurate diagnosis of social situations can enable gay and lesbian youths to assess and navigate potentially hostile social environments (Herdt and Boxer, 1993; McDavitt et al., 2008), well before most people join the workforce and enter an occupation full time. We therefore expect that one set of occupations in which gay and lesbian workers will be overrepresented includes those occupations in which social perceptiveness is important and highly valued. Of course, as in the case of task independence, continued selection and self-selection on the basis of social perceptiveness is likely to contribute to the persistence of this type of segregation, but this pattern may also be further reinforced over time if social perceptiveness leads to a substantial gay or lesbian presence that subsequently draws additional gay and lesbian workers to the occupation. Based on these arguments, we predict:

Hypothesis $2(\mathrm{H} 2)$ : There is a positive relationship between the level of social perceptiveness that an occupation typically requires and the proportion of gay and lesbian workers in the occupation. 
Overall, we hypothesize that gay and lesbian workers will tend to concentrate in occupations that provide a high degree of task independence or require a high level of social perceptiveness, or both. It is worth noting that, to the casual observer, our hypotheses may appear contradictory. It might seem that task independence implies limiting social interactions, while a need for social perceptiveness implies an emphasis on social interactions. In reality, these occupational characteristics are not necessarily at odds, because task independence refers to limited dependence on coworkers and supervisors, while occupations that require social perceptiveness tend to involve interactions with customers, for example, patients, clients, and students.

Consistent with this distinction, our hypotheses posit two separate mechanisms. The first mechanism, underlying $\mathrm{H} 1$, is that task independence facilitates the management of concealable stigma and mitigates the threat of discrimination or mistreatment in the workplace. In contrast, the mechanism behind $\mathrm{H} 2$ is rooted in the development of an above-average capacity for social perceptiveness before entering the workforce. As we noted earlier, independence from coworkers and supervisors is particularly relevant for the first mechanism because abundant research shows that lesbians and gay men experience workplace harassment and discrimination primarily from coworkers and supervisors (e.g., Badgett et al., 2007; Badgett and Frank, 2007) and that they see coworkers and supervisors, rather than customers, as having the greatest impact on their experience at work (HRC, 2009). Thus, in seeking protection from mistreatment and discrimination, independence from coworkers and supervisors is likely to be more important than avoiding customer contact. In turn, our second hypothesis implies that lesbian and gay workers may have a greater aptitude and stronger preference for those occupations that require relatively high levels of social perceptiveness in dealing with customers or clients.

\section{METHODS}

Exploring occupational segregation on the basis of sexual orientation required addressing three main challenges. First, we needed a sufficiently large (and ideally nationally representative) sample in which to identify gay and lesbian individuals and their occupations. Second, we needed information on occupational characteristics, particularly the level of social perceptiveness and task independence associated with a typical position in the occupation. Third, we had to control for several variables that might confound the relationship between sexual orientation and occupational characteristics.

\section{Identifying Gay and Lesbian Workers}

American Community Survey. Our primary data source was the American Community Survey (ACS), the U.S. Census Bureau's largest survey other than the decennial census. The ACS, which replaced the long form of the decennial census in 2010, is conducted in three phases (by mail, then by phone, and, if necessary, by a personal visit). This three-phase design and the mandatory nature of the survey ensure a high response rate. For example, among the ACS sample addresses eligible for interviewing in 2007, approximately 47 percent were polled by mail, 10 percent were interviewed by phone, and 41 percent were represented by in-person interviews; only 2 percent were 
"noninterviews" — cases in which an eligible respondent could not be located, was unavailable, or refused to provide information.

We used ACS data for the years 2008, 2009, and 2010, which provided a representative, 3-percent national random sample of the population and a large enough sample to conduct both occupation-level and individual-level analyses. ACS participants explicitly indicate their relationship to each person in their household (e.g., "'husband or wife,"'"unmarried partner,"'"roommate,"'"roomer or boarder," etc.), as well as the sex of each person. The sex of each respondent's (married or unmarried) partner provides a straightforward indicator of sexual orientation and has been used frequently as a measure of sexual orientation in survey research (e.g., Antecol, Jong, and Steinberger, 2008). ${ }^{\mathbf{5}}$ Of course, one limitation of this indicator is that it captures only those lesbian and gay individuals who are members of a cohabiting (married or unmarried) samesex couple. Despite this limitation, we chose to use the ACS because surveys that ask about sexual orientation more directly do not provide sufficiently large samples. To address the possible limitations of this sexual orientation indicator, we also analyzed a second dataset, which included indicators capturing both coupled and non-coupled gay men and lesbians.

Add Health. Our secondary data source, the U.S. National Longitudinal Study of Adolescent Health (Add Health), is an ongoing study of a sample representative of individuals who were enrolled in grades 7 through 12 in 19941995. Participants were initially interviewed in 1995, and follow-up interviews were conducted in 1996 (Wave 2), 2001-2002 (Wave 3), and 2008-2009 (Wave 4). We used data from Wave 4-when respondents were between 26 and 31 years old-because this wave covers a period when a high proportion of respondents were already employed. Wave 4 included questions relevant to three different aspects of sexual orientation that are not based on relationship status: romantic attraction (to males, females, or both); sexual contact (i.e., history of sexual activity with males, females, or both); and sexual identity, which was measured with the following question: "Please choose the description that best fits how you think about yourself-100-percent homosexual, mostly homosexual, bisexual, mostly heterosexual, 100-percent heterosexual, or not sexually attracted to either males or females." In the analysis reported here, we focus on sexual identity, particularly individuals whose identity was "100percent" or "mostly" homosexual. Scholars see sexual identity "as the most central dimension of sexual orientation that strongly reflects how workers see themselves and how they are treated by colleagues and employers if their sexual orientation is disclosed" (Ueno, Peña-Talamantes, and Roach, 2013: 95). Thus sexual identity captures an important, stable, and ongoing aspect of sexual orientation that needs to be managed in the workplace. ${ }^{\mathbf{6}}$

\footnotetext{
${ }^{\mathbf{5}}$ While some scholars have noted that the Census and the ACS may overestimate the gay population in cases in which the head of the household incorrectly codes the sex of his or her partner, subsequent research indicates that the post-2005 ACS samples provide generally accurate estimates (Gates and Steinberger, 2009).

${ }^{6}$ Our analyses with the other two measures, sexual contact and attraction, showed similar patterns.
} 


\section{Occupational Characteristics}

We matched both our ACS and Add Health data to occupation-level information from the Occupational Information Network (O*NET), a comprehensive database of survey-based occupational ratings that replaced the Dictionary of Occupational Titles as the primary source of information about occupations in the U.S. economy. ${ }^{7}$ O*NET provides occupation-level ratings that describe typical job requirements and worker attributes, as well as the content and context of work in each occupation. As Liu and Grusky (2013: 1334) noted, "O*NET is a rich resource that allows us to directly measure cognitive, creative, technical, and social skills within the detailed occupations of the 2000 Standard Occupational Classification." ${ }^{8}$

Ratings of these occupational characteristics were initially based on ratings by teams of expert occupational analysts but have been and continue to be updated through ongoing surveys of the job incumbents in each occupation's employee population. Job incumbents' ratings are developed by identifying employers in each occupation and then surveying a random sample of their workers about job requirements, worker attributes, and the nature of their work (Tsacoumis and Van Iddekinge, 2006; Fleisher and Tsacoumis, 2012). The ratings on each variable, averaged across raters, are then reported as occupational means.

We measured the level of task independence that an occupation typically provides using the independence item in O*NET (item 1.C.6.). This rating captures the extent to which job incumbents in each occupation indicated that they depend on themselves rather than on coworkers and supervisors to get things done (National Center for O*NET Development, 2013). We measured the level of social perceptiveness required in the occupation using O*NET's social perceptiveness rating (item 2.B.1.a), which captures the degree to which being aware of others' reactions and understanding why they react as they do is essential to the job (National Center for O*NET Development, 2013). O*NET collects task independence ratings on a scale of $1-5$ and social perceptiveness ratings on a scale of $0-7$. For ease of interpretation, we standardized these measures.

\section{Control Variables}

As our review of the literature shows, many existing explanations for the segregation of gay and lesbian workers are idiosyncratic to just a few occupations. The main exception is a sex-typing perspective, which suggests that gay men will be overrepresented in female-dominated occupations, while lesbians will be most commonly found in male-dominated occupations. To incorporate this

\footnotetext{
7 To determine ACS respondents' occupational categories, we used the harmonized occupational codes provided by the Integrated Public Use Microdata Series (IPUMS) because the 2008/2009 ACS and 2010 ACS used different occupational coding schemes (2000 and 2010 Standard Occupational Classification schemes, respectively).

${ }^{8}$ One limitation of O*NET is that it does not collect data on social perceptiveness and several other occupational characteristics for military occupations. Thus our analyses did not include military occupations. But focusing our analysis on civilian occupations is appropriate because the U.S. military had extensive and highly institutionalized employment discrimination policies against gay men and lesbians throughout its modern history until 2011, making it a unique context unrepresentative of the broader occupational landscape.
} 
view, we controlled for the proportion of male workers in the focal occupation. In addition, we controlled for several potential confounds. One important control was education, because higher levels of education might be associated with higher levels of social perceptiveness or task independence in the occupation, as well as a greater likelihood of being in a same-sex couple or claiming a gay or lesbian identity. Similarly, we controlled for urban location because lesbians and gay men may be overrepresented in urban areas (Black et al., 2000) and because social skills, such as social perceptiveness, might be more important in urban jobs (Bacolod, Blum, and Strange, 2009). In addition, our individual-level analyses of ACS data used state dummies to capture geographic variation in legal and cultural environments that shape employment outcomes for sexual minorities (Tilcsik, 2011). These analyses also controlled for race, because attitudes toward homosexuality might vary across racial groups (Glick and Golden, 2010) and because race might affect occupational outcomes. Our individual-level models also controlled for age to account for generational effects.

In addition, we captured whether an occupation is politically conservative or liberal. Lesbian and gay workers may experience less tolerance in highly conservative occupations than in occupations in which the majority of coworkers and supervisors have liberal attitudes (see Pew Research Center, 2014; Tilcsik, 2011). Using campaign finance data on individuals' campaign donations, Bonica $(2010,2014)$ identified the most right-aligned (i.e., conservative) and left-aligned (i.e., liberal) occupations in the United States. While most occupations are politically divided or unaligned, some are reliably conservative (e.g., occupations in the oil, gas, and coal industry), while others are reliably left-aligned (e.g., college professors and occupations in the entertainment industry). We created binary variables indicating left-aligned and right-aligned occupations by manually matching Bonica's (2010) lists of the most ideologically left-leaning and rightleaning industries and occupations to O*NET occupations. All other (i.e., politically not clearly aligned) occupations served as the omitted reference category for these dummy variables.

Finally, we also conducted a series of analyses that controlled for additional O*NET items measuring occupational characteristics that may be correlated with task independence or social perceptiveness. For task independence, one such variable that stood out as particularly important was autonomy. Consistent with the definition of autonomy as freedom in scheduling one's work and in determining the procedures to carry it out (Hackman and Oldham, 1976), the autonomy item in O*NET measures the extent to which workers in an occupation have freedom to plan their work. A second relevant O*NET item was security, which measures the extent to which workers in an occupation tend to have secure employment. Like task independence, job security might be important to gay and lesbian workers because it may limit the harm that can result from the revelation of sexual minority status at work. In addition, we created the variable working alone by taking the additive inverse of the O*NET item capturing the extent to which the occupation "requires preferring to work with others rather than alone." Controlling for this variable is helpful in establishing that it is indeed task independence-rather than simply a preference for solitary work or a lack of interaction with coworkers - that drives segregation patterns. 
For social perceptiveness, we conducted supplementary analyses with all other O*NET items that measure the importance of different occupational social skills: coordination, persuasion, negotiation, instructing (i.e., teaching others how to do something), and service orientation (i.e., actively looking for ways to help people). Because the need for these other social skills in an occupation might be correlated with the need for social perceptiveness, controlling for these items allows us to establish that it is indeed social perceptiveness, rather than social skills more generally, that is associated with segregation patterns. As part of this analysis, we also reran our models while controlling for the O*NET item customer and personal service orientation, which captures how important it is in the occupation to have knowledge of customer service principles and processes. This control variable allows us to provide evidence that the results for social perceptiveness are not simply capturing differences in knowledge of customer service practices. In addition, it enables us to test our hypothesis about task independence (i.e., that the relevant kind of independence for segregation is from coworkers and supervisors) while simultaneously controlling for the level of interactions with customers.

\section{Analytic Approach}

We conducted three types of analysis. First, we used ACS data at the occupational level, examining the relationship between the proportion of gay and lesbian workers in the occupation and the extent to which the occupation requires social perceptiveness and provides task independence. This analysis was a good starting point because it provided a comprehensive overview of the occupational landscape and highlighted how the representation of lesbian and gay workers varies with occupational characteristics. At the same time, occupationlevel analyses might fail to control appropriately for relevant worker-level characteristics (Robinson, 1950). Thus, as a second step, we analyzed ACS data at the individual level. Finally, to examine the robustness of our results to sexual orientation indicators not based on couple status, we conducted individual-level analyses with the Add Health data.

Our sample for the ACS analyses included 452 occupations and 4.9 million individuals. ${ }^{9}$ These data included 30,343 individuals (.62 percent of the entire sample) who were members of a gay or lesbian household. While this proportion may appear low, it should be noted that it refers to the number of individuals who are members of a cohabiting same-sex couple as a proportion of all (including non-coupled) individuals. When comparing same-sex cohabiting couples with other cohabiting couples, the proportion of gay and lesbian workers is in line with expectations: among households with cohabiting partners, 9.3 percent were gay and lesbian households. In the Add Health data, which provided an effective sample of 2,527 individuals, roughly 2 percent identified as gay or lesbian, 7 percent reported same-sex romantic attraction, and 10 percent reported same-sex sexual contact. These numbers are consistent with other

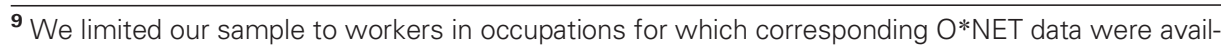
able. O*NET data were unavailable for some occupations when the occupational code in ACS or Add Health referred to "all other" categories or to classifications for which O*NET did not provide a clearly matching occupation. The proportion of lesbian and gay workers, and our control variables, did not significantly differ between occupations with and without corresponding O*NET data.
} 
data sources on the demographics of sexual orientation (Gates, 2011; Gates and Newport, 2012; Stephens-Davidowitz, 2014). ${ }^{\mathbf{1 0}}$

\section{RESULTS \\ Occupation-level Analysis}

As a first descriptive pass at the ACS data, we generated lists of occupations with the highest proportion of gay and lesbian workers. Table 1 lists 15 occupations in which both the proportion of gay men among male workers and the proportion of lesbians among female workers are above average, sorted in descending order by the total proportion of gay men and lesbians among all workers. Table 2 separately lists female-majority occupations (i.e., those in which more than 50 percent of all workers are women) and male-majority occupations (i.e., those in which more than 50 percent of all workers are men) with the highest proportion of gay workers and the highest proportion of lesbian

\section{Table 1. Occupations with the Highest Proportion of Both Gay and Lesbian Workers*}

1. Psychologists (S, T)

2. Training and development specialists and managers (S)

3. Social and community service managers $(\mathrm{S}, \mathrm{T})$

4. Technical writers (T)

5. Occupational therapists $(S, T)$

6. Massage therapists $(S, T)$

7. Urban and regional planners $(S, T)$

8. Producers and directors $(S, T)$

9. Postsecondary teachers (S, T)

10. Probation officers and correctional treatment specialists $(S, T)$

11. Morticians, undertakers, and funeral directors (S)

12. Physical therapists and exercise physiologists $(S, T)$

13. Computer and information systems managers $(S, T)$

14. Lawyers, judges, magistrates, and other judicial workers $(S, T)$

15. Web developers (T)

* S denotes above-average social perceptiveness, and T denotes above-average task independence associated with the occupation. Because measurement error is more likely in rare occupations with a very low number of workers, the smallest 5 percent of occupations (by total number of workers in ACS) were excluded.

\footnotetext{
${ }^{10}$ A potential problem in research on concealable stigma is that those who reveal themselves as members of a stigmatized group for research purposes might be more willing to reveal their identity at work or in everyday interactions. Several features of our data help mitigate such concerns. First, the proportion of gay men and lesbians in our samples is in line with prior research, including completely anonymous surveys (Knight, Tilcsik, and Anteby, 2014) and research that circumvents selfreporting problems (Stephens-Davidowitz, 2014), which suggests that fears of disclosure did not cause our samples to miss a substantial portion of the target population. Second, our main sexual orientation indicator is based on whether a person lives with a same-sex partner as captured by the nationally representative ACS. Those sampled for the ACS are legally obligated to answer all questions accurately. Third, ACS information is mailed to addresses without individual names, which protects the confidentiality of participating households and thus mitigates concerns about disclosure. Fourth, even though the number of respondents coded as lesbian and gay varies (in an expected way) depending on whether sexual orientation is defined based on couple status, identity, romantic attraction, or sexual contact, our results were consistent across all these definitions.
} 


\section{Table 2. Female- and Male-majority Occupations with Highest Proportion of Gay or Lesbian Workers*}

Female-majority occupations

1. Psychologists (S, T)

2. Probation officers/correctional treatment specialists ${ }^{\dagger}(S, T)$

3. Training and development specialists and managers (S)

4. Sociologists $(\mathrm{S}, \mathrm{T})$

5. Social and community service managers $(S, T)$
1. Flight attendants (S)

2. Hairdressers, hairstylists, and cosmetologists (S, T)

3. Nurse practitioners $(S, T)$

4. Transportation attendants, except flight attendants (S)

5. Travel agents (S, T)

Male-majority occupations

\author{
1. Bus and truck mechanics and diesel engine specialists \\ 2. Elevator installers/repairers ( $\mathrm{T}$ ) \\ 3. Heating, $A / C$, and refrigeration mechanics/installers $(T)$ \\ 4. Home appliance repairers (T) \\ 5. Security and fire alarm systems installers (T)
}

\author{
1. Actors $(\mathrm{S}, \mathrm{T})$ \\ 2. News analysts, reporters, and correspondents $(S, T)$ \\ 3. Artists and related workers (S, T) \\ 4. Agents/managers of artists, performers, athletes $(S, T)$ \\ 5. Producers and directors (S, T)
}

* S denotes above-average social perceptiveness, and T denotes above-average task independence associated with the occupation. Because measurement error is more likely in rare occupations with a very low number of workers, we excluded the smallest 5 percent of occupations (by total number of workers in ACS).

${ }^{\dagger}$ Even though most probationers and parolees are male, this is a female-majority occupation by a slight margin.

workers. In both tables, nearly all of the occupations are associated with above-average task independence or social perceptiveness, or both.

We began our regression analysis with a basic, occupation-level investigation of the ACS data. In addition to the main independent variables, these analyses controlled for the proportion of workers in the occupation who hold a college degree, the proportion of workers who live in a metropolitan area, the proportion of male workers, the proportion of white workers, and dummy variables indicating left-aligned and right-aligned occupations. ${ }^{11}$ Table 3 displays descriptive statistics and correlations for this analysis. Table 4 presents regression results. Because the dependent variables in these regressions are proportions, we used fractional logit regression models (Papke and Wooldridge, 1996). ${ }^{12}$ These three models include the same independent variables but differ in the dependent variable. In model 1 , the dependent variable is the proportion of all workers in the occupation who are either gay or lesbian. In model 2, it is the proportion of all male workers who are gay. In model 3 , it is the proportion of all female workers who are lesbians.

\footnotetext{
11 Despite a previously common myth, it is now well established that the use of proportion (i.e., ratio) variables with common components does not lead to bias in regression analysis. Nevertheless, for robustness, we also reran these models without the control variables and found similar results, which were also confirmed by our individual-level analyses that did not use ratio variables.

12 To account for the fact that our dependent variables (i.e., the proportion of gay/lesbian workers) in these models are derived from a sample (the ACS), rather than the entire population itself, our models in table 4 weighted each occupation by the inverse of its standard error around the relevant dependent variable (i.e., the proportion of gay and/or lesbian workers). Thus more precise estimates of these proportions were given greater influence than less precise estimates. The results relevant to our hypotheses also remained robust when not using these weights.
} 
Table 3. Descriptive Statistics and Correlations for Occupation-level ACS Data

\begin{tabular}{|c|c|c|c|c|c|c|c|c|c|c|c|c|}
\hline Variable & Mean & S.D. & 1 & 2 & 3 & 4 & 5 & 6 & 7 & 8 & 9 & 10 \\
\hline $\begin{array}{l}\text { 1. Proportion of all workers } \\
\text { who are gay or lesbian }\end{array}$ & .01 & .004 & & & & & & & & & & \\
\hline $\begin{array}{l}\text { 2. Proportion of male } \\
\text { workers who are gay }\end{array}$ & .01 & .012 & .62 & & & & & & & & & \\
\hline $\begin{array}{l}\text { 3. Proportion of female } \\
\text { workers who are lesbians }\end{array}$ & .01 & .017 & .05 & -.16 & & & & & & & & \\
\hline 4. Task independence & 0 & 1 & .34 & .26 & -.02 & & & & & & & \\
\hline 5. Social perceptiveness & 0 & 1 & .49 & .29 & -.08 & .33 & & & & & & \\
\hline $\begin{array}{l}\text { 6. Proportion of } \\
\text { college-educated } \\
\text { workers }^{*}\end{array}$ & .30 & .295 & .55 & .24 & -.12 & .32 & .67 & & & & & \\
\hline $\begin{array}{l}\text { 7. Proportion of workers } \\
\text { in urban areas* }\end{array}$ & .74 & .136 & .41 & .28 & -.16 & .16 & .42 & .54 & & & & \\
\hline $\begin{array}{l}\text { 8. Proportion of } \\
\text { male workers* }\end{array}$ & .61 & .279 & -.39 & -.50 & .45 & -.27 & -.31 & -.22 & -.34 & & & \\
\hline $\begin{array}{l}\text { 9. Proportion of } \\
\text { white workers* }\end{array}$ & .78 & .082 & .15 & .04 & .27 & .19 & .28 & .30 & -.09 & .21 & & \\
\hline $\begin{array}{l}\text { 10. Left-aligned } \\
\text { occupation }\end{array}$ & .03 & .179 & .17 & .07 & -.04 & .12 & .07 & .18 & .15 & -.10 & .09 & \\
\hline $\begin{array}{l}\text { 11. Right-aligned } \\
\text { occupation }\end{array}$ & .10 & .306 & -.23 & -.14 & .14 & -.08 & -.20 & -.20 & -.24 & .30 & .09 & -.06 \\
\hline
\end{tabular}

* The regression models in tables 4 and 5 use the standardized versions of these variables, but for the purpose of descriptive reporting, this table displays means and standard deviations for the original, unstandardized variables.

Table 4. Occupation-level Analysis with ACS Data: Fractional Logit Models Predicting the Proportion of Gay and Lesbian Workers in the Occupation*

\begin{tabular}{|c|c|c|c|}
\hline Variable & $\begin{array}{l}\text { Model } 1 \\
\text { Gay and lesbian } \\
\text { workers as proportion } \\
\text { of all workers }\end{array}$ & $\begin{array}{l}\text { Model } 2 \\
\text { Gay men as } \\
\text { proportion of } \\
\text { male workers }\end{array}$ & $\begin{array}{l}\text { Model } 3 \\
\text { Lesbians as } \\
\text { proportion of } \\
\text { female workers }\end{array}$ \\
\hline Task independence & $\begin{array}{l}.10^{\bullet \bullet} \\
(.03)\end{array}$ & $\begin{array}{l}.14^{\bullet \bullet} \\
(.05)\end{array}$ & $\begin{array}{l}.10^{\bullet} \\
(.05)\end{array}$ \\
\hline Social perceptiveness & $\begin{array}{l}.10^{\bullet} \\
(.04)\end{array}$ & $\begin{array}{l}.10^{\bullet} \\
(.05)\end{array}$ & $\begin{array}{l}.12^{\bullet} \\
(.06)\end{array}$ \\
\hline Proportion of college-educated workers & $\begin{array}{l}.17^{\bullet \bullet \bullet} \\
(.05)\end{array}$ & $\begin{array}{r}.09 \\
(0.06)\end{array}$ & $\begin{array}{r}-.23^{\bullet} \\
(.09)\end{array}$ \\
\hline Proportion of workers in urban areas & $\begin{array}{l}.13^{\bullet} \\
(.05)\end{array}$ & $\begin{array}{l}.32^{\bullet \bullet \bullet} \\
(.09)\end{array}$ & $\begin{array}{l}0.11 \\
(.10)\end{array}$ \\
\hline Proportion of male workers & $\begin{array}{l}-.16^{\bullet \bullet \bullet} \\
(.03)\end{array}$ & $\begin{array}{l}-.72^{\bullet \bullet \bullet} \\
(.04)\end{array}$ & $\begin{array}{l}.74^{\bullet \bullet \bullet} \\
(.06)\end{array}$ \\
\hline Proportion of white workers & $\begin{array}{c}.04 \\
(.03)\end{array}$ & $\begin{array}{c}.09^{\bullet} \\
(.04)\end{array}$ & $\begin{array}{l}.29^{\bullet \bullet \bullet} \\
(.06)\end{array}$ \\
\hline Left-aligned occupations & $\begin{array}{l}.12 \\
(.12)\end{array}$ & $\begin{array}{r}-.06 \\
(.19)\end{array}$ & $\begin{array}{c}.04 \\
(.25)\end{array}$ \\
\hline Right-aligned occupations & $\begin{array}{c}-.34^{\bullet \bullet} \\
(.11)\end{array}$ & $\begin{array}{c}-.04 \\
(.14)\end{array}$ & $\begin{array}{c}-.09 \\
(.17)\end{array}$ \\
\hline Constant & $\begin{array}{c}-5.35^{\bullet \bullet \bullet} \\
(.03)\end{array}$ & $\begin{array}{c}-5.52^{\bullet \bullet \bullet} \\
(.04)\end{array}$ & $\begin{array}{c}-4.60^{\bullet \bullet \bullet} \\
(.04)\end{array}$ \\
\hline $\begin{array}{l}\text { Log pseudo-likelihood } \\
\chi^{2}\end{array}$ & $\begin{array}{r}-161.6 \\
338.6\end{array}$ & $\begin{array}{r}-257.7 \\
545.3\end{array}$ & $\begin{array}{r}-527.2 \\
223.1\end{array}$ \\
\hline \multicolumn{4}{|c|}{$\begin{array}{l}{ }^{\bullet} p<.05 ; \bullet p<.01 ; \cdots p<.001 . \\
* N=452 . \text { Robust standard errors are in parentheses. We standardized all independent variables, except for the } \\
\text { two dummy variables (left-aligned occupations and right-aligned occupations). } \\
\text { Downloaded from asq.sagepub.com at Yale University Library on March 11, } 2015\end{array}$} \\
\hline
\end{tabular}


The first noteworthy pattern in these models is that they replicate the observation from previous research that the proportion of gay men is higher in female-dominated occupations than in male-dominated occupations (model 2), while the opposite is true for lesbians (model 3). Even after controlling for this effect, however, we find support for our hypotheses. Across all three models, both task independence and social perceptiveness have a positive, significant relationship to the proportion of gay or lesbian workers in an occupation. ${ }^{13}$

Post-estimation margins calculations suggested that this relationship is significant not only statistically but also substantively. Holding the control variables constant at their averages, model 1 predicts that when social perceptiveness and task independence are both high (i.e., one standard deviation above the mean), the proportion of lesbian and gay workers is 1.5 times higher than it is when social perceptiveness and task independence are both low (i.e., one standard deviation below the mean). Similarly, model 3 predicts that when social perceptiveness and task independence are both high, the proportion of female workers who are lesbians is 1.6 times as high as it is when social perceptiveness and task independence are both low.

As noted above, we also conducted a series of analyses that controlled for additional O*NET items that may be related to task independence or social perceptiveness. These analyses, displayed in table 5, control for coordination, persuasion, negotiation, instructing, service orientation, customer and personal service, security, autonomy, and working alone. Because many of these variables are highly correlated with one another and with the independent variables of interest, we entered them separately into the regression equations to avoid multicollinearity problems. ${ }^{14}$ Across all these models, the positive coefficients on task independence and social perceptiveness remain statistically significant, except the social perceptiveness coefficient in model 4. In contrast, none of the additional O*NET items are statistically significant predictors of the proportion of gay and lesbian workers in an occupation. Thus our results are generally robust to the inclusion of these other occupational variables.

Further analysis suggests that our key independent variables have substantial predictive power in identifying gay and lesbian occupations. For example, a simple descriptive overview of the occupation-level ACS data indicates that knowing nothing but a single fact about an occupation-whether it is above or below the median in social perceptiveness-allows one to correctly predict whether that occupation is above or below the median in the proportion of gay and lesbian workers in 73 percent of all cases. That is, the simple assumption that occupations will be above the median in the proportion of lesbian and gay workers if (and only if) they are above the median in social perceptiveness is a surprisingly accurate rule of thumb. While chance alone would provide a correct answer only half of the time, knowledge of just this one fact leads to a substantial improvement in prediction, providing the correct answer nearly three-quarters of the time. Also, this rule of thumb remains equally effective when restricting the sample to occupations that

\footnotetext{
${ }^{13}$ Additional models indicated no statistically significant interaction between task independence and social perceptiveness, suggesting that these variables have an additive, rather than interactive, effect on the proportion of lesbian and gay workers.

${ }^{14}$ When all these variables are entered into a single equation, variance inflation factors associated with task independence and social perceptiveness indicate multicollinearity problems.

Nevertheless, even in this equation, the coefficient on task independence remains statistically significant, and none of the additional O*NET items have a significant coefficient.
} 
Table 5. Supplementary Occupation-level Analysis with ACS Data: Fractional Logit Models Predicting the Proportion of Gay and Lesbian Workers in the Occupation*

\begin{tabular}{|c|c|c|c|c|c|c|c|c|c|}
\hline Variable & Model 4 & Model 5 & Model 6 & Model 7 & Model 8 & Model 9 & Model 10 & Model 11 & Model 12 \\
\hline Task independence & $\begin{array}{l}.10^{\bullet \bullet} \\
(.03)\end{array}$ & $\begin{array}{l}.10 \bullet \bullet \\
(.03)\end{array}$ & $\begin{array}{l}.10^{\bullet \bullet} \\
(.03)\end{array}$ & $\begin{array}{l}.10^{\circ \bullet} \\
(.03)\end{array}$ & $\begin{array}{l}.10^{\bullet \bullet} \\
(.03)\end{array}$ & $\begin{array}{l}.09 \bullet \bullet \\
(.03)\end{array}$ & $\begin{array}{l}.09 \bullet \bullet \\
(.03)\end{array}$ & $\begin{array}{l}.09 \cdot \bullet \\
(.03)\end{array}$ & $\begin{array}{l}.10^{\bullet \bullet} \\
(.03)\end{array}$ \\
\hline $\begin{array}{l}\text { Social } \\
\text { perceptiveness }\end{array}$ & $\begin{array}{l}.09 \\
(.05)\end{array}$ & $\begin{array}{l}.10^{\bullet} \\
(.05)\end{array}$ & $\begin{array}{l}.09^{\bullet} \\
(.04)\end{array}$ & $\begin{array}{l}.12^{\bullet} \\
(.05)\end{array}$ & $\begin{array}{l}.09^{\bullet} \\
(.04)\end{array}$ & $\begin{array}{l}.08^{\bullet} \\
(.04)\end{array}$ & $\begin{array}{l}.11^{\bullet} \\
(.04)\end{array}$ & $\begin{array}{l}.09^{\bullet} \\
(.04)\end{array}$ & $\begin{array}{l}.11^{\bullet} \\
(.05)\end{array}$ \\
\hline Coordination & $\begin{array}{l}.02 \\
(.05)\end{array}$ & & & & & & & & \\
\hline Persuasion & & $\begin{array}{l}.01 \\
(.04)\end{array}$ & & & & & & & \\
\hline Negotiation & & & $\begin{array}{l}.00 \\
(.04)\end{array}$ & & & & & & \\
\hline Instructing & & & & $\begin{array}{r}-.02 \\
(.04)\end{array}$ & & & & & \\
\hline $\begin{array}{l}\text { Service } \\
\text { orientation }\end{array}$ & & & & & $\begin{array}{l}.02 \\
(.04)\end{array}$ & & & & \\
\hline $\begin{array}{l}\text { Customer and } \\
\text { personal service }\end{array}$ & & & & & & $\begin{array}{l}.05 \\
(.04)\end{array}$ & & & \\
\hline Security & & & & & & & $\begin{array}{l}.03 \\
(.04)\end{array}$ & & \\
\hline Autonomy & & & & & & & & $\begin{array}{l}.03 \\
(.04)\end{array}$ & \\
\hline Working alone & & & & & & & & & $\begin{array}{l}.00 \\
(.04)\end{array}$ \\
\hline $\begin{array}{l}\text { Proportion of } \\
\text { college-educated } \\
\text { workers }\end{array}$ & $\begin{array}{l}.17^{\bullet \bullet \bullet} \\
(.05)\end{array}$ & $\begin{array}{l}.17^{\bullet \bullet \bullet} \\
(.04)\end{array}$ & $\begin{array}{l}.17^{\bullet \bullet \bullet} \\
(.05)\end{array}$ & $\begin{array}{l}.18^{\bullet \bullet \bullet} \\
(.05)\end{array}$ & $\begin{array}{l}.17^{\bullet \bullet \bullet} \\
(.04)\end{array}$ & $\begin{array}{l}.19^{\bullet \bullet \bullet} \\
(.04)\end{array}$ & $\begin{array}{l}.13^{\bullet \bullet} \\
(.05)\end{array}$ & $\begin{array}{l}.16^{\bullet \bullet \bullet} \\
(.05)\end{array}$ & $\begin{array}{l}.17^{\bullet \bullet \bullet} \\
(.04)\end{array}$ \\
\hline $\begin{array}{l}\text { Proportion of } \\
\text { workers in } \\
\text { urban areas }\end{array}$ & $\begin{array}{l}.13^{\bullet} \\
(.05)\end{array}$ & $\begin{array}{l}.13^{\bullet} \\
(.05)\end{array}$ & $\begin{array}{l}.14 \\
(.07)\end{array}$ & $\begin{array}{l}.13^{\bullet} \\
(.05)\end{array}$ & $\begin{array}{l}.13^{\bullet} \\
(.05)\end{array}$ & $\begin{array}{l}.11^{\bullet} \\
(.05)\end{array}$ & $\begin{array}{l}.16^{\bullet \bullet \bullet} \\
(.04)\end{array}$ & $\begin{array}{l}.13^{\bullet} \\
(.05)\end{array}$ & $\begin{array}{l}.13^{\bullet} \\
(.05)\end{array}$ \\
\hline $\begin{array}{l}\text { Proportion of } \\
\text { male workers }\end{array}$ & $\begin{array}{c}-.17^{\bullet \bullet \bullet} \\
(.04)\end{array}$ & $\begin{array}{c}-.16^{\bullet \bullet \bullet} \\
(.03)\end{array}$ & $\begin{array}{c}-.17^{\bullet \bullet \bullet} \\
(.03)\end{array}$ & $\begin{array}{c}-.16^{\bullet \bullet \bullet} \\
(.03)\end{array}$ & $\begin{array}{c}-.16^{\bullet \bullet \bullet} \\
(.04)\end{array}$ & $\begin{array}{c}-.15^{\bullet \bullet \bullet} \\
(.03)\end{array}$ & $\begin{array}{c}-.16^{\bullet \bullet \bullet} \\
(.03)\end{array}$ & $\begin{array}{c}-.17^{\bullet \bullet \bullet} \\
(.03)\end{array}$ & $\begin{array}{l}-.16^{\bullet \bullet \bullet} \\
(.03)\end{array}$ \\
\hline $\begin{array}{l}\text { Proportion of } \\
\text { white workers }\end{array}$ & $\begin{array}{l}.04 \\
(.03)\end{array}$ & $\begin{array}{l}.04 \\
(.03)\end{array}$ & $\begin{array}{l}.05 \\
(.04)\end{array}$ & $\begin{array}{l}.04 \\
(.03)\end{array}$ & $\begin{array}{l}.04 \\
(.03)\end{array}$ & $\begin{array}{l}.04 \\
(.03)\end{array}$ & $\begin{array}{l}.06 \\
(.03)\end{array}$ & $\begin{array}{l}.04 \\
(.03)\end{array}$ & $\begin{array}{l}.04 \\
(.03)\end{array}$ \\
\hline $\begin{array}{l}\text { Left-aligned } \\
\text { occupations }\end{array}$ & $\begin{array}{l}.13 \\
(.12)\end{array}$ & $\begin{array}{l}.12 \\
(.12)\end{array}$ & $\begin{array}{l}.10 \\
(.10)\end{array}$ & $\begin{array}{l}.11 \\
(.13)\end{array}$ & $\begin{array}{l}.13 \\
(.13)\end{array}$ & $\begin{array}{l}.14 \\
(.13)\end{array}$ & $\begin{array}{l}.14 \\
(.12)\end{array}$ & $\begin{array}{l}.13 \\
(.12)\end{array}$ & $\begin{array}{l}.12 \\
(.12)\end{array}$ \\
\hline $\begin{array}{r}\text { Right-aligned } \\
\text { occupations }\end{array}$ & $\begin{array}{c}-.35^{\bullet \bullet} \\
(.11)\end{array}$ & $\begin{array}{c}-.34^{\bullet \bullet} \\
(.11)\end{array}$ & $\begin{array}{r}-.29^{*} \\
(.13)\end{array}$ & $\begin{array}{c}-.34^{\bullet \bullet} \\
(.11)\end{array}$ & $\begin{array}{c}-.34 \bullet \bullet \\
(.11)\end{array}$ & $\begin{array}{l}-.35^{\bullet \bullet} \\
(.11)\end{array}$ & $\begin{array}{c}-.30^{\bullet \bullet} \\
(.12)\end{array}$ & $\begin{array}{c}-.34 \bullet \bullet \\
(.12)\end{array}$ & $\begin{array}{c}-.34 \bullet \bullet \\
(.11)\end{array}$ \\
\hline Constant & $\begin{array}{c}-5.35^{\bullet \bullet \bullet} \\
(.03)\end{array}$ & $\begin{array}{c}-5.35^{\bullet \bullet \bullet} \\
(.03)\end{array}$ & $\begin{array}{c}-5.24^{\bullet \bullet \bullet} \\
(.03)\end{array}$ & $\begin{array}{c}-5.35^{\bullet \bullet \bullet} \\
(.03)\end{array}$ & $\begin{array}{c}-5.35^{\bullet \bullet \bullet} \\
(.03)\end{array}$ & $\begin{array}{c}-5.35^{\bullet \bullet \bullet} \\
(.03)\end{array}$ & $\begin{array}{c}-5.37^{\circ \bullet \bullet} \\
(.03)\end{array}$ & $\begin{array}{c}-5.35^{\bullet \bullet \bullet} \\
(.03)\end{array}$ & $\begin{array}{c}-5.35^{\bullet \bullet} \\
(.03)\end{array}$ \\
\hline $\begin{array}{l}\text { Log } \\
\text { pseudo-likelihood }\end{array}$ & -161.6 & -161.6 & -13.22 & -161.6 & -161.6 & -161.6 & -145.2 & -161.6 & -161.6 \\
\hline$\chi^{2}$ & 340.0 & 339.2 & 319.4 & 337.8 & 341.6 & 338.3 & 315.3 & 340.4 & 339.3 \\
\hline
\end{tabular}

$\bullet p<.05 ; \bullet p<.01 ; \cdots p<.001$

${ }^{*} N=452$, except in model 10 , for which $N=412$. Robust standard errors are in parentheses. We standardized all independent variables, except for the two dummy variables (left-aligned occupations and right-aligned occupations).

are not strongly sex-typed (those in which neither sex has a larger than 55percent share) or occupations that are sex-typed (e.g., those in which one sex has at least a 65-percent share).

\section{Individual-level Analysis}

Table 6 (ACS) and table 7 (Add Health) display descriptive statistics and correlations for our individual-level analyses. Table 8 presents regression results for 
Table 6. Descriptive Statistics and Correlations for Individual-level ACS Data

\begin{tabular}{|c|c|c|c|c|c|c|c|c|c|c|c|c|c|c|c|c|c|}
\hline Variable & Mean & S.D. & 1 & 2 & 3 & 4 & 5 & 6 & 7 & 8 & 9 & 10 & 11 & 12 & 13 & 14 & 15 \\
\hline $\begin{array}{l}\text { 1. Task } \\
\text { independence }\end{array}$ & 0 & 1 & & & & & & & & & & & & & & & \\
\hline $\begin{array}{l}\text { 2. Social } \\
\text { perceptiveness }\end{array}$ & 0 & 1 & .46 & & & & & & & & & & & & & & \\
\hline 3. Gay & .003 & .06 & .01 & .02 & & & & & & & & & & & & & \\
\hline 4. Lesbian & .003 & .06 & .01 & .02 & .00 & & & & & & & & & & & & \\
\hline $\begin{array}{l}\text { 5. Heterosexual } \\
\text { female }\end{array}$ & .489 & .50 & .18 & .15 & -.05 & -.06 & & & & & & & & & & & \\
\hline 6. Urban area & 2.579 & 1.29 & .03 & .05 & .01 & .01 & .00 & & & & & & & & & & \\
\hline 7. White & .795 & .40 & .05 & .06 & .01 & .01 & -.02 & -.06 & & & & & & & & & \\
\hline 8. Black & .096 & .29 & -.03 & -.04 & -.01 & -.01 & .04 & .02 & -.64 & & & & & & & & \\
\hline 9. Asian & .048 & .21 & .02 & .02 & .00 & -.01 & .01 & .07 & -.44 & -.07 & & & & & & & \\
\hline 10. High school & .357 & .48 & -.14 & -.25 & -.01 & -.01 & -.02 & -.07 & .01 & .03 & -.07 & & & & & & \\
\hline 11. Some college & .248 & .43 & .02 & .02 & .00 & .00 & .05 & .00 & 0 & .03 & -.03 & -.43 & & & & & \\
\hline $\begin{array}{l}\text { 12. College and } \\
\text { higher }\end{array}$ & .296 & .46 & .25 & .40 & .02 & .02 & .01 & .09 & .05 & -.08 & .11 & -.48 & -.37 & & & & \\
\hline 13. Single & .23 & .42 & -.16 & -.15 & -.03 & -.03 & -.02 & .02 & -.11 & .11 & .00 & .00 & .02 & -.09 & & & \\
\hline $\begin{array}{l}\text { 14. Living with } \\
\text { unmarried } \\
\text { partner }\end{array}$ & .063 & .24 & -.03 & -.03 & .20 & .21 & -.02 & .00 & .00 & .00 & -.03 & .02 & .00 & -.04 & -.14 & & \\
\hline $\begin{array}{l}\text { 15. Proportion } \\
\text { of men in } \\
\text { occupation }\end{array}$ & .512 & .30 & -.32 & -.26 & .00 & -.01 & -.59 & -.03 & .03 & -.04 & -.02 & .08 & -.07 & -.07 & -.04 & .01 & \\
\hline 16. Age & 43.28 & 15.1 & .16 & .13 & .01 & .00 & -.02 & -.03 & .10 & -.04 & -.03 & .02 & -.05 & .09 & -.50 & -.11 & .04 \\
\hline
\end{tabular}

Table 7. Descriptive Statistics and Correlations for Individual-level Add Health Data

\begin{tabular}{|c|c|c|c|c|c|c|c|c|c|c|c|c|c|c|c|c|}
\hline Variable & Mean & S.D. & 1 & 2 & 3 & 4 & 5 & 6 & 7 & 8 & 9 & 10 & 11 & 12 & 13 & 14 \\
\hline 1. Task independence & 0 & 1 & & & & & & & & & & & & & & \\
\hline 2. Social perceptiveness & 0 & 1 & 69 & & & & & & & & & & & & & \\
\hline 3. Gay & .01 & .09 & .03 & .05 & & & & & & & & & & & & \\
\hline 4. Lesbian & .01 & .08 & .01 & .03 & -.01 & & & & & & & & & & & \\
\hline 5. Heterosexual female & .56 & .50 & -.10 & .15 & -.11 & -.09 & & & & & & & & & & \\
\hline 6. White & .74 & .44 & .09 & .05 & -.05 & .02 & -.05 & & & & & & & & & \\
\hline 7. Black & .22 & .41 & -.10 & -.07 & .06 & -.02 & .05 & -.89 & & & & & & & & \\
\hline 8. Asian & .03 & .18 & .03 & .03 & -.02 & -.01 & .02 & -.31 & -.10 & & & & & & & \\
\hline 9. High school & .26 & .44 & -.19 & -.22 & -.05 & .01 & -.05 & -.02 & .02 & -.04 & & & & & & \\
\hline 10. Some college & .34 & .47 & -.08 & -.05 & .00 & .00 & .03 & .02 & -.01 & -.04 & -.43 & & & & & \\
\hline 11. College & .34 & .47 & .34 & .34 & .04 & .00 & .04 & .00 & -.02 & .09 & -.43 & -.52 & & & & \\
\hline 12. Single & .29 & .45 & .00 & -.01 & .10 & .02 & -.05 & -.13 & .12 & .03 & -.10 & -.02 & .09 & & & \\
\hline $\begin{array}{l}\text { 13. Living with } \\
\text { unmarried partner }\end{array}$ & .26 & .44 & -.10 & -.09 & -.01 & .05 & -.01 & -.07 & .07 & .00 & .04 & .06 & -.11 & -.38 & & \\
\hline 14. Age & 28.36 & 1.82 & .01 & -.01 & -.01 & -.03 & -.08 & -.02 & -.01 & .06 & .08 & -.03 & -.05 & -.12 & -.09 & \\
\hline $\begin{array}{l}\text { 15. Proportion of men } \\
\text { in occupation }\end{array}$ & .49 & .29 & .23 & -.20 & .00 & -.03 & -.56 & .06 & -.06 & -.01 & .13 & -.05 & -.1 & -.03 & .02 & .10 \\
\hline
\end{tabular}

both the ACS sample (models 13 and 14) and the Add Health sample (models 15 and 16). These models predict the level of task independence and social perceptiveness in the focal individual's occupation as a function of sexual orientation, while controlling for race, education, marital or cohabitation status (with 
Table 8. Individual-level Analysis with ACS and Add Health Data: Seemingly Unrelated Regression Models Predicting Social Perceptiveness and Task independence*

\begin{tabular}{|c|c|c|c|c|}
\hline \multirow[b]{2}{*}{ Variable } & \multicolumn{2}{|c|}{ American Community Survey } & \multicolumn{2}{|c|}{ Add Health } \\
\hline & $\begin{array}{c}\text { Task independence } \\
\text { Model } 13\end{array}$ & $\begin{array}{c}\text { Social perceptiveness } \\
\text { Model } 14\end{array}$ & $\begin{array}{l}\text { Task independence } \\
\text { Model } 15\end{array}$ & $\begin{array}{c}\text { Social perceptiveness } \\
\text { Model } 16\end{array}$ \\
\hline \multirow[t]{2}{*}{ Gay } & $.21^{\bullet \bullet \bullet}$ & $.18^{\bullet \bullet \bullet}$ & $.33^{\bullet}$ & $.56^{\bullet}$ \\
\hline & $(.01)$ & $(.01)$ & $(.17)$ & $(.23)$ \\
\hline \multirow[t]{2}{*}{ Lesbian } & $.19^{\bullet \bullet \bullet}$ & $.20^{\bullet \bullet \bullet}$ & $.37^{\bullet \bullet}$ & $.47^{\bullet}$ \\
\hline & $(.01)$ & $(.01)$ & (.13) & $(.20)$ \\
\hline \multirow[t]{2}{*}{ Heterosexual female } & $.01^{\bullet \bullet \bullet}$ & $.01^{\bullet \bullet \bullet}$ & .11 & .15 \\
\hline & $(.00)$ & $(.00)$ & $(.06)$ & $(.11)$ \\
\hline \multirow[t]{2}{*}{ White } & $.13^{\bullet \bullet \bullet}$ & $.12^{\bullet \bullet \bullet}$ & .02 & -.12 \\
\hline & $(.00)$ & $(.00)$ & $(.15)$ & $(.17)$ \\
\hline \multirow[t]{2}{*}{ Black } & $.04^{\bullet \cdots}$ & $.08^{\bullet \bullet \bullet}$ & -.13 & -.25 \\
\hline & $(.00)$ & $(.00)$ & $(.15)$ & $(.16)$ \\
\hline \multirow[t]{2}{*}{ Asian } & $.02^{\bullet \bullet \bullet}$ & $.01^{\bullet}$ & -.03 & -.13 \\
\hline & $(.00)$ & $(.00)$ & $(.16)$ & $(.17)$ \\
\hline \multirow[t]{2}{*}{ High school } & $.30^{\bullet \bullet \bullet}$ & $.28^{\bullet \bullet \bullet}$ & $.34^{\bullet \bullet}$ & $.28^{\bullet \bullet}$ \\
\hline & $(.00)$ & $(.00)$ & $(.10)$ & $(.10)$ \\
\hline \multirow[t]{2}{*}{ Some college } & $.63^{\bullet \bullet \bullet}$ & $.61^{\bullet \bullet \bullet}$ & $.63^{\bullet \bullet}$ & $.55^{\bullet \bullet \bullet}$ \\
\hline & $(.00)$ & $(.00)$ & $(.11)$ & $(.11)$ \\
\hline \multirow[t]{2}{*}{ College } & $1.26^{\bullet \bullet \bullet}$ & $1.16^{\bullet \bullet \bullet}$ & $1.21^{\bullet \bullet \bullet}$ & $1.07^{\bullet \bullet \bullet}$ \\
\hline & $(.00)$ & $(.00)$ & $(.14)$ & $(.15)$ \\
\hline \multirow[t]{2}{*}{ Single } & $-.28^{\bullet \bullet \bullet}$ & $-.22^{\bullet \bullet \bullet}$ & $-.10^{\bullet}$ & $-.15^{\bullet}$ \\
\hline & $(.00)$ & $(.00)$ & $(.05)$ & $(.06)$ \\
\hline \multirow[t]{2}{*}{ Living with unmarried partner } & $-.13^{\bullet \bullet \bullet}$ & $-.11^{\bullet \bullet \bullet}$ & $-.19^{\bullet \bullet \bullet}$ & $-.18^{\bullet \bullet \bullet}$ \\
\hline & $(.00)$ & $(.00)$ & $(.05)$ & $(.05)$ \\
\hline \multirow[t]{2}{*}{ Age } & $.00^{\bullet \bullet \bullet}$ & $.00^{\bullet \bullet \bullet}$ & -.00 & .01 \\
\hline & $(.00)$ & $(.00)$ & $(.01)$ & $(.01)$ \\
\hline \multirow[t]{2}{*}{ Urban area } & $.01^{\bullet \bullet \bullet}$ & $.01^{\bullet \bullet \bullet}$ & & \\
\hline & $(.00)$ & $(.00)$ & & \\
\hline \multirow{2}{*}{$\begin{array}{l}\text { Proportion of males } \\
\text { in occupation }\end{array}$} & $.56^{\bullet \bullet \bullet}$ & $-.71^{\bullet \bullet}$ & $1.05^{\bullet \bullet \bullet}$ & -.39 \\
\hline & $(.00)$ & $(.00)$ & $(.25)$ & $(.28)$ \\
\hline State dummies & Yes & Yes & No & No \\
\hline \multirow[t]{2}{*}{ Constant } & $-1.20^{\bullet \bullet \bullet}$ & $-.45^{\bullet \bullet}$ & $-1.19^{\bullet \bullet}$ & -.46 \\
\hline & $(.00)$ & $(.00)$ & (.38) & $(.38)$ \\
\hline $\mathrm{N}$ & $4,917,367$ & $4,917,367$ & 2,527 & 2,527 \\
\hline $\mathrm{R}^{2}$ & .26 & .26 & .22 & .18 \\
\hline
\end{tabular}

$\bullet p<.05 ; \bullet p<.01 ; \cdots p<.001$.

* Robust standard errors, clustered at the occupation level, are in parentheses.

"married" as the omitted category), and age at the individual level, as well as the proportion of men in the occupation. In addition, the ACS models control for the individual's urban location and include state dummies. (The public-use Add Health data do not provide this information.) Within each dataset, the two models are estimated as seemingly unrelated regressions (Baltagi, 1980; Wooldridge, 2002), thus accounting for any correlation of errors between the equations. Robust standard errors are clustered at the occupation level. Because these models include dummy variables indicating gay, lesbian, and heterosexual female workers, the omitted reference category refers to heterosexual men. 
In models 13 and 14, to which we applied the person-sampling weights of the ACS, the significant positive coefficient for the variable gay indicates that gay men tend to be in occupations with higher task independence and social perceptiveness than heterosexual men. Similarly, post-estimation tests comparing the coefficient on the lesbian and the heterosexual female variables show that lesbians tend to be in occupations with significantly higher task independence and social perceptiveness than heterosexual women $(p<.001){ }^{15}$ It is important to note that the large sample size in the ACS analyses allowed for substantial statistical power, which (appropriately) reduced standard errors. Nevertheless, as a robustness check, we subsequently recalibrated all $p$-values in these models so that they reflected a fixed sample size of 1,000 individuals (Good, 1992; Woolley, 2003), and our coefficients of interest remained significant even after this adjustment. Moreover, additional split-sample analyses have shown that both those gay men and lesbians who are in occupations in which they are a gender minority and those who are in occupations in which they are a gender majority tend to be in occupations with relatively high task independence and required social perceptiveness.

Finally, models 15 and 16, which use the relevant cross-sectional weights of the Add Health data, examine whether our results hold up when using an indicator of sexual orientation that also captures non-coupled gay and lesbian workers. These models show that both gay men and lesbians tend to be in occupations with higher levels of social perceptiveness and task independence than heterosexual men (the reference category). For example, compared with heterosexual men, the estimated level of social perceptiveness in the occupation is one-third standard deviation higher for gay workers and one-half standard deviation higher for lesbians (model 16). Moreover, when comparing lesbians with heterosexual women, the coefficient for lesbians is higher than it is for heterosexual women with regard to both task independence and social perceptiveness at the $p<.10$ level. Overall, results from the Add Health data are consistent with our hypotheses-even in this smaller, age-restricted sample, and even when using a measure of sexual orientation that is independent of couple status.

\section{DISCUSSION}

The occupational segregation patterns of gay and lesbian workers present a longstanding puzzle. Ever since Ellis's (1897) observations more than a century ago, numerous scholars have documented the unusually high concentration of gay and lesbian workers in certain occupations, but the list of these occupations seems to be largely haphazard, with few apparent commonalities among them. As our analyses show, these occupations vary greatly in their prestige and task profile, ranging from psychologists and postsecondary teachers to probation officers and massage therapists (see tables 1 and 2). Given this puzzling heterogeneity, systematic accounts of gay and lesbian occupational segregation have remained elusive.

\footnotetext{
15 As a robustness check, we also ran analyses on a subsample of only those individuals who lived in a same-sex or opposite-sex unmarried-partner household. Results from these analyses closely mirror those in models 13 and 14.
} 
One important exception has been the observation that gay and lesbian workers are more likely than heterosexual workers to cross gender lines in occupations (Baumle, Compton, and Poston, 2009). Although this observation is consistent with many empirical findings, it does not account for malemajority occupations with a high proportion of gay men and female-majority occupations with a high proportion of lesbians-even though nearly half of (partnered) gay men work in male-majority occupations and two-thirds of (partnered) lesbians work in female-majority occupations. Nor does this observation account for occupations in which both lesbian and gay workers are overrepresented, such as those listed in table 1. In this study, we offer a new perspective that explains lesbian and gay segregation patterns above and beyond (i.e., controlling for) the tendency of these workers to traverse occupational gender boundaries.

\section{Toward a Theory of Gay and Lesbian Occupations}

Building on Goffman's (1963) classic insights into concealable stigma, we identified two patterns that underlie the occupational landscape for gay and lesbian workers. Fundamental to both of our hypotheses is the idea that occupational segregation is shaped by gay and lesbian workers' adaptation to potential discrimination and the dilemmas of disclosure that they face both in the workplace and beyond. Our results suggest that this framework can parsimoniously explain a large set of seemingly random patterns across the occupational spectrum. While gay men are more likely to be in female-dominated occupations than are heterosexual men, and lesbians are more highly represented in maledominated occupations than are heterosexual women, common to both gay men and lesbians is a tendency to concentrate in occupations that provide task independence or require social perceptiveness, or both.

A focus on social perceptiveness and task independence can also explain many previous observations about lesbian and gay jobs. As noted earlier, for example, one finding that a sex-typing perspective could not account for is that both gay and lesbian workers are often concentrated in professions that focus on creativity, psychology, counseling, law, and social work (Baumle, Compton, and Poston, 2009). Clearly, working in these fields requires a non-trivial degree of social perceptiveness, perhaps most obviously in the case of psychology, counseling, and social work, but also in creative or artistic fields, in which perception of social conditions and audiences plays an important role. Some of these fields (e.g., creative jobs and psychology) also tend to provide a relatively high level of task independence.

Similarly, many artistic, service-oriented, and care-focused occupations commonly associated with gay men require an above-average level of social perceptiveness. Awareness and anticipation of others' reactions and mental states-whether they are patients in a healthcare setting, passengers on a plane, audience members in a theatre, or students in a classroom-are relatively important components of many such jobs. Likewise, the (only partially accurate) observation that lesbians might be drawn to highly "masculine" bluecollar work can be explained in a more nuanced and empirically accurate way if one notes that lesbian workers are especially likely to be found in those maledominated, blue-collar jobs that provide an above-average degree of task independence. It is quite striking, for example, that four of the five male-majority 
occupations with the highest proportion of lesbian workers are various repairers and installers with an above-average degree of task independence (table 2). Thus rather than simply reflecting an innate sensibility of gay men for artistic or caring jobs, or a natural attraction of lesbians to "masculine" jobs, these occupational patterns might be more effectively understood in terms of social perceptiveness and task independence, factors that reflect social adaptation to concealable stigma in the workplace and beyond.

The notion that social perceptiveness due to the need for stigma management plays a key role in occupational segregation suggests implications for both the past and the future of gay and lesbian work. For example, the labor historian Bérubé's (2011: 265) research into the gay labor movement led him to ask, "How do people find queer work and how do they make these jobs their own?" By "queer work," Bérubé meant work that is often performed by, or has the reputation of being performed by, homosexual men and women. His question stemmed from, for example, the observed concentration of gay men in a handful of military jobs during World War II and in steward jobs on ocean liners after the war. By identifying some possible dimensions of "queer work," our study's findings start to answer Bérubé's question.

Our study suggests, for example, that the "special talents" that some observers attributed to gay soldiers during World War II might not be fully imaginary (Bérubé, 1990: 57). Being a hospital corpsman, a navy yeoman, or a chaplain's assistant-jobs in which gay men were believed to congregate in the military - may have required a higher degree of social perceptiveness than many other military occupations. Attending to wounded soldiers' medical and emotional needs, to navy officers' clerical needs, or to soldiers' religious comfort are tasks in which the understanding of others' needs, reactions, emotions, and cognitive states is likely to play a non-trivial role. Similarly, social perceptiveness is likely to have been integral to the work of ship stewards, a servicefocused role involving frequent interactions with passengers. It is important to emphasize, however, that what earlier observers saw as a perhaps innate "special talent" we conceptualize as the result of social adaptation to concealable stigma.

One implication of this view is that, in the long run, the possible de-stigmatization of minority sexual orientation may weaken the relationships that we have documented. In particular, in societies that become more tolerant of same-sex relationships, the need for stigma management in everyday social interactions (Goffman, 1963) might fade over time. Intriguingly, as broader tolerance alleviates the intense and ongoing need for managing stigma-related information in everyday life, it might also lead to a relative "deskilling" of gay and lesbian workers with respect to social perceptiveness. Put otherwise, these workers might lose their distinctiveness (Anteby and Anderson, 2014). At the same time, the patterns that we observed are likely to remain in place for a significant period of time. Even if de-stigmatization took place rapidly, broad occupational patterns are slow to change because they continue to reflect earlier educational and career choices and because network-based mechanisms (such as homophily in job referrals) might also help maintain segregation patterns that had initially emerged as a response to stigmatization (see Marquis and Tilcsik, 2013). 


\section{Concealable Stigma, Occupations, and Labor Markets}

Our study also suggests implications for the broader field of research on stigma and labor markets. In line with our arguments, theorists building on Goffman's work have highlighted the relationship between the revelation of concealable stigmatized attributes and social rejection (Kulik, Bainbridge, and Cregan, 2008) and the resulting dilemmas of disclosure across life domains (Ragins, 2008). This line of theorizing has also hinted at the possibility that stigmatization may have some "potential positive functions" for an individual (Paetzold, Dipboye, and Elsbach, 2008: 187), such as, in our context, higher levels of social perceptiveness (Knight, Tilcsik, and Anteby, 2014). Most of this literature, however, has focused on the individual or intra-organizational level of analysis, and few studies have linked stigmatization to larger structural outcomes (Fiske, 1998). We begin to address this gap by identifying the consequences of one type of concealable stigma on the broader occupational landscape.

Our theoretical framework also suggests some testable baseline hypotheses for understanding the occupational implications of other types of concealable stigma, such as minority political or religious beliefs, mental illness, or less apparent physical illnesses (e.g., HIV). The aspects of concealable stigma on which we focused when developing our predictions-the need for social adaptation given the dilemmas of disclosure and the threat of potential discovery-have been documented not only among lesbian and gay workers but across a variety of other stigmatized groups (Pachankis, 2007). At the same time, while the relationships we describe might apply to concealable stigma more generally, additional factors that may be unique to other stigmatized groups can complicate these patterns. Ultimately, questions about the applicability of our argument to other types of concealable stigma will need to be settled empirically, but our theory does provide testable baseline hypotheses with which to examine concealable stigma and occupational segregation more generally.

Finally, our findings are relevant for the literature on employment discrimination. While field experimental (audit) studies have convincingly established that discrimination on the basis of race (Bertrand and Mullainathan, 2004), motherhood (Correll, Benard, and Paik, 2007), and sexual orientation (Tilcsik, 2011) continues to play an important role in many labor markets, much less is known about how job seekers might change their behavior in response to discrimination. In the case of sexual orientation, for example, previous work has "documented the existence of discrimination, but . . . [did not] explore how gay job seekers adapt to this reality" and could only "capture the extent of discrimination that occurs before job seekers' responses to discrimination ... take place" (Tilcsik, 2011: 619; see also Heckman, 1998). Our findings suggest that gay and lesbian workers might be drawn to a different set of occupations than heterosexual workers and may also bring with them a distinct set of skills. Accounting for these differences in future audit researchrather than assuming otherwise completely equivalent job seekers who apply for the exact same set of jobs-might provide new insights into patterns of employment discrimination that sexual minorities experience in contemporary labor markets. 


\section{Future Research}

We have identified occupational characteristics that shape lesbian and gay segregation patterns, but the effects of these patterns on other outcomes, such as wages or career mobility, were beyond the scope of this study. Because there is already a literature on wage differences by sexual orientation (e.g., Badgett, 1995; Clain and Leppel, 2001; Klawitter, 2015), we focused instead on the puzzling occupational profiles of gay and lesbian workers. Future research would benefit from exploring the implications of the relationships we uncovered on wage distribution, as well as additional workplace outcomes, such as job-level segregation or the demographic composition of organizations. At this time, however, high-quality labor market data on sexual orientation are still rare. Nationally representative surveys have only just begun to include sexual orientation, which currently prevents scholars from tracking the long-term evolution of gay and lesbian occupations. A promising next step may be to collect smaller-scale data on how gay, lesbian, and heterosexual job applicants choose jobs to target; such data might uncover finer-grained mechanisms of occupational segregation. In-depth archival and qualitative inquiries into lesbians' and gay men's entry trajectories into specific occupations might also add to our understanding of these fine-grained mechanisms. By linking concealable stigma to broad patterns in the occupational landscape, our study takes a first step in that direction and develops a new perspective on segregation dynamics in contemporary labor markets.

\section{Acknowledgments}

We thank Roxana Barbulescu, Forrest Briscoe, Sameer Srivastava, Dan Schrage, and Bruce Western for helpful comments; Associate Editor Martin Kilduff and three anonymous reviewers for their thorough and constructive criticism; Linda Johanson and Joan Friedman for excellent editorial suggestions; and Caitlin Anderson for her research assistance. We also greatly benefited from feedback by participants at the 2013 May Meaning Meeting, the 6th Annual People and Organizations Conference at Wharton, and the Harvard Cultural Sociology Workshop. This research uses data from Add Health, a program project directed by Kathleen Mullan Harris and designed by J. Richard Udry, Peter S. Bearman, and Kathleen Mullan Harris at the University of North Carolina at Chapel Hill, and funded by grant P01-HD31921 from the Eunice Kennedy Shriver National Institute of Child Health and Human Development, with cooperative funding from 23 other federal agencies and foundations. Special acknowledgment is due to Ronald R. Rindfuss and Barbara Entwisle for assistance in the original design. Information on how to obtain the Add Health data files is available on the Add Health website (http://www.cpc.unc.edu/addhealth). No direct support was received from grant P01-HD31921 for this analysis.

\section{REFERENCES}

Allegra, D.

1996 "She tickles with a hammer." In K. Gray (ed.), Dyke Life: From Growing Up to Growing Old—A Celebration of the Lesbian Experience: 282-288. London: Pandora. American Psychological Association

1993 Resolution on Lesbian, Gay, and Bisexual Youths in the Schools. Washington, DC: American Psychological Association. 
Anderson, L. R., and L. Randlet

1993 "Self-monitoring and life satisfaction of individuals with traditional and nontraditional sexual orientations." Basic and Applied Social Psychology, 14: 345-361.

Anteby, M., and C. Anderson

2014 "The shifting landscape of LGBT organizational research." In A. P. Brief and B. M. Staw (eds.), Research in Organizational Behavior, 34: 3-25. New York: Elsevier/ JAI.

Antecol, H., A. Jong, and M. Steinberger

2008 "The sexual orientation wage gap: The role of occupational sorting and human capital." Industrial and Labor Relations Review, 61: 518-543.

Bacolod, M., B. S. Blum, and W. C. Strange

2009 "Skills in the city." Journal of Urban Economics, 65: 136-153.

Badgett, M. V. L.

1995 "The wage effects of sexual orientation discrimination." Industrial and Labor Relations Review, 48: 726-739.

Badgett, M. V. L., and J. Frank 2007 Sexual Orientation Discrimination: An International Perspective. Abingdon, UK: Routledge.

Badgett, M. V. L., and M. C. King 1997 "Lesbian and gay occupational strategies." In A. Gluckman and B. Reed (eds.), Homo Economics: Capitalism, Community, and Lesbian and Gay Life: 73-85. New York: Routledge.

Badgett, M. V. L., H. Lau, B. Sears, and D. Ho 2007 "Bias in the workplace: Consistent evidence of sexual orientation and gender identity discrimination." Williams Institute, University of California School of Law.

Bailey, J. M., and M. Oberschneider 1997 "Sexual orientation and professional dance." Archives of Sexual Behavior, 26: 433-444.

Baltagi, B. H. 1980 "On seemingly unrelated regressions with error components." Econometrica, 48: 1547-1551.

Barbulescu, R., and M. Bidwell 2013 "Do women choose different jobs from men? Mechanisms of application segregation in the market for managerial workers." Organization Science, 24: 737-756.

Baumle, A. K., D. L. R. Compton, and D. L. Poston 2009 Same-sex Partners: The Demography of Sexual Orientation. Albany, NY: SUNY Press.

Berger, R. M. 1982 Gay and Gray: The Older Homosexual Man. Urbana, IL: University of Illinois Press.

Bertrand, M., and S. Mullainathan 2004 "Are Emily and Greg more employable than Lakisha and Jamal? A field experiment on labor market discrimination." American Economic Review, 94: 991-1013.

Bérubé, $A$.

1990 Coming Out under Fire: The History of Gay Men and Women in World War Two. New York: Free Press.

Bérubé, $A$.

2011 "'Queer work' and labor history." In J. D'Emilio and E. B. Freedman (eds.), My Desire for History: Essays in Gay, Community, and Labor History: 259-269. Chapel Hill, NC: University of North Carolina Press.

Bidwell, M., F. Briscoe, I. Fernandez-Mateo, and A. Sterling 2013 "The employment relationship and inequality: How and why changes in employment practices are reshaping rewards in organizations." Academy of Management Annals, 7 (1): 61-121. 
Black, D., G. Gates, S. Sanders, and L. Taylor

2000 "Demographics of the gay and lesbian population in the United States: Evidence from available systematic data sources." Demography, 37: 139-154.

Blair-Loy, M.

2001 "Cultural constructions of family schemas: The case of women executives." Gender and Society, 15: 687-709.

Blandford, J. M.

2003 "The nexus of sexual orientation and gender in the determination of earnings." Industrial and Labor Relations Review, 56: 622-642.

Bonica, A.

2010 "Ideologically aligned and ideologically divided industries." http://ideologicalcartography.com/2010/02/27/which-industries-are-polarized-and-which-are-just-polarizing/.

Bonica, A.

2014 "Mapping the ideological marketplace." American Journal of Political Science, 58: 367-386.

Bourdieu, P. 2001 Masculine Domination. Cambridge, UK: Polity Press.

Breaugh, J. A. 1985 "The measurement of work autonomy." Human Relations, 38: 551-570.

Budig, M. J., and P. England 2001 "The wage penalty for motherhood." American Sociological Review, 66: 204-225

Chauncey, G.

1994 Gay New York: Gender, Urban Culture, and the Making of the Gay Male World, 1890-1940. New York: Basic Books.

Clain, S. H., and K. Leppel

2001 "An investigation into sexual orientation discrimination as an explanation for wage differences." Applied Economics, 33 (1): 37-47.

Connell, C.

2015 School's Out: Gay and Lesbian Teachers in the Classroom. Oakland, CA: University of California Press.

Correll, S. J., S. Benard, and I. Paik

2007 "Getting a job: Is there a motherhood penalty?" American Journal of Sociology, 112: 1297-1338.

Croteau, J. M.

1996 "Research on the work experiences of lesbian, gay, and bisexual people: An integrative review of methodology and findings." Journal of Vocational Behavior, 48: 195-209.

D'Augelli, A. R., and A. H. Grossman

2001 "Disclosure of sexual orientation, victimization, and mental health among lesbian, gay, and bisexual older adults." Journal of Interpersonal Violence, 16: 10081027.

D'Augelli, A. R., and S. L. Hershberger 1993 "Lesbian, gay, and bisexual youth in community settings: Personal challenges and mental health problems." American Journal of Community Psychology, 21: 421448.

Dobbin, F., J. R. Sutton, J. W. Meyer, and W. R. Scott 1993 "Equal-opportunity law and the construction of internal labor-markets." American Journal of Sociology, 99: 396-427.

Drydakis, N. 2009 "Sexual orientation discrimination in the labour market." Labour Economics, 16 (4): 364-372.

Drydakis, N.

2015 "Effect of sexual orientation on job satisfaction: Evidence from Greece. "Industrial Relations, 54: 162-187. 
Ellis, $\mathrm{H}$.

1897 Sexual Inversion. London: F. A. Davis Company.

Emerson, R. M.

1962 "Power-dependence relations." American Sociological Review, 27: 31-41.

England, P., M. Chassie, and L. McCormack

1982 "Skill demands and earnings in female and male occupations." Sociology and

Social Research, 66: 147-168.

England, P., M. S. Herbert, B. S. Kilbourne, L. L. Reid, and L. M. Megdal

1994 "The gendered valuation of occupations and skills: Earnings in 1980 Census

occupations." Social Forces, 73: 65-100.

Escoffier, J.

1975 "Stigmas, work environment, and economic discrimination against homosexuals." Homosexual Counseling Journal, 2: 8-17.

Fassinger, R. E.

1995 "From invisibility to integration: Lesbian identity in the workplace." Career

Development Quarterly, 44: 148-167.

Fernandez, R. M., and C. Friedrich

2011 "Gender sorting at the application interface." Industrial Relations: A Journal of Economy and Society, 50: 591-609.

Fernandez-Mateo, I., and Z. King

2011 "Anticipatory sorting and gender segregation in temporary employment." Management Science, 57: 989-1008.

Fiske, S. T.

1998 "Stereotyping, prejudice, and discrimination." In D. T. Gilbert and S. T. Fiske

(eds.), The Handbook of Social Psychology: 357-411. Boston: McGraw Hill.

Fleisher, M. S., and S. Tsacoumis

2012 "O*NET analyst occupational skills ratings: Procedures update." Raleigh, NC:

National Center for O*NET Development.

Flynn, F. J., J. A. Chatman, and S. E. Spataro

2001 "Getting to know you: The influence of personality on impressions and perfor-

mance of demographically different people in organizations." Administrative Science Quarterly, 46: 414-442.

Gates, G. J.

2011 "How many people are lesbian, gay, bisexual, and transgender?" Williams Institute, University of California Law School.

Gates, G. J., and F. Newport

2012 "3.4\% of U.S. adults identify as LGBT." Washington, DC: Gallup. http:// www.gallup.com/poll/158066/special-report-adults-identify-lgbt.aspx.

Gates, G. J., and M. D. Steinberger

2009 "Same-sex unmarried partner couples in the American Community Survey: The role of misreporting, miscoding and misallocation." Paper presented at the Annual Meeting of the Population Association of America, Detroit, MI.

Gilbert, J. A., and J. L. Kottke

2009 "Developing a measure of social perceptiveness." Paper presented at the Annual Conference of the Association for Psychological Science, San Francisco.

Glick, S. N., and M. R. Golden 2010 "Persistence of racial differences in attitudes toward homosexuality in the United States." Journal of Acquired Immune Deficiency Syndromes, 55: 516-523.

Goffman, E. 1963 Stigma: Notes on the Management of Spoiled Identity. New York: Simon \& Schuster.

Good, I. J.

1992 "The Bayes/non-Bayes compromise: A brief review." Journal of the American Statistical Association, 87: 597-606. 
Hackman, J. R., and G. R. Oldham

1976 "Motivation through the design of work: Test of a theory." Organizational Behavior and Human Performance, 16: 250-279.

Hansen, J. C., and B. J. Dik

2004 "Measures of career interests." In M. Herson and J. C. Thomas (eds.), Handbook of Psychological Assessment, vol. 4: Industrial/Organizational Assessment: 166-191. New York: Wiley.

Harry, J., and W. B. DeVall

1978 The Social Organization of Gay Males. New York: Praeger.

Heckman, J. J. 1998 "Detecting discrimination." Journal of Economic Perspectives, 12: 101-116.

Herdt, G., and A. Boxer

1993 Children of Horizons: How Gay and Lesbian Teens Are Leading a New Way Out of the Closet. Boston: Beacon Press.

Hetherington, $\mathrm{C}$., and $\mathrm{A}$. Orzek

1989 "Career counseling and life planning with lesbian women." Journal of Counseling and Development, 68: 52-57.

Hetrick, E. S., and A. D. Martin

1984 "Ego-dystonic homosexuality: A developmental view." In E. S. Hetrick and T. S. Stein (eds.), Innovations in Psychotherapy with Homosexuals: 2-21. Washington, DC: American Psychiatric Press.

Hetrick, E. S., and A. D. Martin

1987 "Developmental issues and their resolution for gay and lesbian adolescents." Journal of Homosexuality, 14: 25-43.

Hewitt, C.

1995 "The socioeconomic position of gay men: A review of evidence." American Journal of Economics and Sociology, 54: 461-479.

Hochschild, A. R.

1983 The Managed Heart: Commercialization of Human Feeling. Berkeley, CA: University of California Press.

Holland, J. L.

1997 Making Vocational Choices, 3rd ed. Odessa, FL: PAR, Inc.

HRC (Human Rights Campaign)

2009 "Degrees of equality: A national study examining workplace climate for LGBT employees." http://www.hrc.org/documents/HRC_Degrees_of_Equality_2009.pdf.

Huebner, D. M., G. M. Rebchook, and S. M. Kegeles

2004 "Experiences of harassment, discrimination, and physical violence among young gay and bisexual men." American Journal of Public Health, 94: 1200-1203.

Kalev, A., F. Dobbin, and E. Kelly 2006 "Best practices or best guesses? Assessing the efficacy of corporate affirmative action and diversity policies." American Sociological Review, 71: 589-617.

Kanter, R. M.

1977 Men and Women in the Corporation. New York: Basic Books.

Kaufman, R. L.

2002 "Assessing alternative perspectives on race and sex employment segregation." American Sociological Review, 67: 547-572.

Kidd, J. M.

1984 "Young people's perceptions of their occupational decision-making." British Journal of Guidance and Counseling, 12: 25-38.

Kiggundu, M. N.

1981 "Task interdependence and the theory of job design." Academy of Management Review, 6: 499-508. 
Kiggundu, M. N.

1983 "Task interdependence and job design: Test of a theory." Organizational Behavior and Human Performance, 31: 145-172.

Kilduff, M., and D. V. Day

1994 "Do chameleons get ahead? The effects of self-monitoring on managerial careers." Academy of Management Journal, 37: 1047-1060.

Klawitter, M.

2015 "Meta-analysis of the effect of sexual orientation on earnings. "Industrial Relations, 54: 4-32.

Klein, J. A.

1991 "A reexamination of autonomy in light of new manufacturing practices." Human Relations, 44: 21-38.

Knight, C., A. Tilcsik, and M. Anteby

2014 "Differences in occupational skills and preferences by sexual orientation: A research note." Harvard University Working Paper. http://papers.ssrn.com/sol3/ papers.cfm?abstract_id=2511625.

Kulik, C. T., H. T. J. Bainbridge, and C. Cregan 2008 "Known by the company we keep: Stigma-by-association effects in the workplace." Academy of Management Review, 33: 216-230.

Kyei, P., and J. Madden

2013 "Gender differences in the gay pay gap: Unmeasured gender-linked characteristics, household division of labor, or greater bias against gay men?" Paper presented at the APPAM Annual Fall Research Conference, Washington, DC.

Lance, T. S., M. Z. Anderson, and J. M. Croteau

2010 "Improving measurement of workplace sexual identity management." Career Development Quarterly, 59: 19-26.

Lent, R. W., S. D. Brown, and G. Hackett 1994 "Toward a unifying social cognitive theory of career and academic interest, choice, and performance." Journal of Vocational Behavior, 45: 79-122.

Lipkin, A.

1999 Understanding Homosexuality, Changing Schools: A Text for Teachers, Counselors, and Administrators. Boulder, CO: Westview Press.

Liu, Y., and D. B. Grusky

2013 "The payoff to skill in the third industrial revolution." American Journal of Sociology, 118: 1330-1374.

Mandel, $\mathrm{H}$.

2013 "Up the down staircase: Women's upward mobility and the wage penalty for occupational feminization, 1970-2007." Social Forces, 91: 1183-1207.

Marquis, C., and A. Tilcsik

2013 "Imprinting: Toward a multilevel theory." Academy of Management Annals, 7: 193-243.

Martin, A. D., and E. S. Hetrick

1988 "The stigmatization of the gay and lesbian adolescent." Journal of Homosexuality, 15: 163-183.

Martin, S. E. 1980 Breaking and Entering: Policewomen on Patrol. Berkeley, CA: University of California Press.

McDavitt, B., E. Iverson, K. Kubicek, G. Weiss, C. F. Wong, and M. D. Kipke 2008 "Strategies used by gay and bisexual young men to cope with heterosexism." Journal of Gay and Lesbian Social Services, 20 (4): 354-380.

Mehra, A., M. J. Kilduff, and D. J. Brass

2001 "The social networks of high and low self-monitors: Implications for workplace performance." Administrative Science Quarterly, 46: 121-146. 
Morgeson, F. P., M. H. Reider, and M. A. Campion

2005 "Selecting individuals in team settings: The importance of social skills, personality characteristics, and teamwork knowledge." Personnel Psychology, 58: 583-611.

National Center for O*NET Development 2013 "The O*NET content model: Detailed outline with descriptions." http://www. onetcenter.org/dl_files/ContentModel_DetailedDesc.pdf.

National Center for O*NET Development 2014 "About O*NET." http://www.onetcenter.org/overview.html.

Ng, E. S., L. Schweitzer, and S. T. Lyons

2012 "Anticipated discrimination and a career choice in nonprofit: A study of early career lesbian, gay, bisexual, transgendered (LGBT) job seekers." Review of Public Personnel Administration, 32 (4): 332-352.

Pachankis, J. E. 2007 "The psychological implications of concealing a stigma: A cognitive-affectivebehavioral model." Psychological Bulletin, 133 (2): 328-345.

Padavic, I., and B. F. Reskin 1994 Women and Men at Work. Thousand Oaks, CA: Pine Forge Press.

Paetzold, R. L., R. L. Dipboye, and K. D. Elsbach 2008 "A new look at stigmatization in and of organizations." Academy of Management Review, 33: 186-193.

Pager, D., B. Western, and B. Bonikowski 2009 "Discrimination in a low-wage labor market: A field experiment." American Sociological Review, 74: 777-799.

Papke, L. E., and J. M. Wooldridge

1996 "Econometric methods for fractional response variables with an application to 401 (k) plan participation rates." Journal of Applied Econometrics, 11: 619-632.

Pascoe, C. J.

2007 Dude, You're a Fag: Masculinity and Sexuality in High School. Berkeley, CA: University of California Press.

Peterson, N. G., M. D. Mumford, W. C. Borman, P. R. Jeanneret, and E. A. Fleishman 1999 An Occupational Information System for the 21st Century: The Development of O*NET. Washington, DC: APA.

\section{Pew Research Center} 2014 "Beyond red vs. blue: The political typology." http://www.people-press.org/ 2014/06/26/the-political-typology-beyond-red-vs-blue/.

Poteat, V. P., and D. L. Espelage 2007 "Predicting psychosocial consequences of homophobic victimization in middle school students." Journal of Early Adolescence, 27: 175-191.

Powell, B., C. Bolzendahl, C. Geist, and L. Carr Steelman 2010 Counted Out: Same-Sex Relations and Americans' Definitions of Family. New York: Russell Sage Foundation.

Radkowsky, M., and L. J. Siegel 1997 "The gay adolescent: Stressors, adaptations, and psychosocial interventions." Clinical Psychology Review, 17: 191-216.

Ragins, B. R. 2004 "Sexual orientation in the workplace: The unique work and career experiences of gay, lesbian and bisexual workers." In J. Martocchio (ed.), Research in Personnel and Human Resources Management, 23: 35-120. Bingley, UK: Emerald Books.

Ragins, B. R.

2008 "Disclosure disconnects: Antecedents and consequences of disclosing invisible stigmas across life domains." Academy of Management Review, 33: 194-215. 
Ragins, B. R., and J. M. Cornwell

2001 "Pink triangles: Antecedents and consequences of perceived workplace discrimination against gay and lesbian employees." Journal of Applied Psychology, 86: 1244-1261.

Ragins, B. R., R. Singh, and J. M. Cornwell 2007 "Making the invisible visible: Fear and disclosure of sexual orientation at work." Journal of Applied Psychology, 92: 1103-1118.

Reimann, R. 2001 "Lesbian mothers at work." In M. Bernstein and R. Reimann (eds.), Queer Families, Queer Politics: Challenging Culture and the State: 254-271. New York: Columbia University Press.

Reskin, B. F. 1993 "Sex segregation in the workplace." Annual Review of Sociology, 19: 241-270.

\section{Reskin, B. F., and P. A. Roos}

1987 "Status hierachies and sex segregation." In C. Bose and G. Spitze (eds.), Ingredients for Women's Employment Policy: 3-21. Albany, NY: State University of New York Press.

Robinson, W. S. 1950 "Ecological correlations and the behavior of individuals." American Sociological Review, 15: 351-357.

Sedlovskaya, A., V. Purdie-Vaughns, R. P. Eibach, M. LaFrance, R. Romero-Canyas, and N. P. Camp

2013 "Internalizing the closet: Concealment heightens the cognitive distinction between public and private selves." Journal of Personality and Social Psychology, 104: 695-715.

Sherman, R.

2007 Class Acts: Service and Inequality in Luxury Hotels. Berkeley, CA: University of California Press.

Simons, H. W.

1966 "Authoritarianism and social perceptiveness." Journal of Social Psychology, 68: 291-297.

Smart, L., and D. M. Wegner 1999 "Covering up what can't be seen: Concealable stigma and mental control." Journal of Personality and Social Psychology, 77: 474-486.

Snyder, M.

1987 Public Appearances, Private Realities: The Psychology of Self-Monitoring. New York: Freeman.

Stephens-Davidowitz, S.

2014 "Estimating the closeted gay male population." Paper presented at the Centers for Disease Control and Prevention STD Conference, June 10, Atlanta, GA.

Stern, I., and J. D. Westphal 2010 "Stealthy footsteps to the boardroom: Executives' backgrounds, sophisticated interpersonal influence behavior, and board appointments." Administrative Science Quarterly, 55: 278-319.

Taulke-Johnson, R. 2008 "Moving beyond homophobia, harassment and intolerance: Gay male university students' alternative narratives." Discourse: Studies in the Cultural Politics of Education, 29: 121-133.

Tilcsik, A.

2011 "Pride and prejudice: Employment discrimination against openly gay men in the United States." American Journal of Sociology, 117: 586-626.

Tsacoumis, S., and C. H. Van Iddekinge

2006 "A comparison of incumbent and analyst ratings of O*NET Skills." Raleigh, NC: National Center for O*NET Development. 
Ueno, K., A. E. Peña-Talamantes, and T. A. Roach

2013 "Sexual orientation and occupational attainment." Work and Occupations, 40

(1): 3-36.

Ward, J., and D. Winstanley

2005 "Coming out at work: Performativity and the recognition and renegotiation of identity." Sociological Review, 53: 447-475.

Whitam, F. L.

1986 Male Homosexuality in Four Societies: Brazil, Guatemala, the Philippines, and the United States. New York: Praeger.

Williams, C. L.

1992 "The glass escalator: Hidden advantages for men in the 'female' professions."

Social Problems, 39: 253-267.

Williams, C. L.

1995 Still a Man's World: Men Who Do "Women's Work." Berkeley, CA: University of California Press.

Woods, J. D.

1994 The Corporate Closet. New York: Free Press.

Wooldridge, J. M.

2002 Econometric Analysis of Cross Section and Panel Data. Cambridge, MA: MIT Press.

Woolley, T. W.

2003 "The p-value, the Bayes/Neyman-Pearson Compromise and the teaching of statistical inference in introductory business statistics." http://abeweb.org/proceedings/ proceedings03/woolley.pdf.

Xie, Y., and K. A. Shauman

1997 "Modeling the sex-typing of occupational choice: Influences of occupational structure." Sociological Methods and Research, 26: 233-261.

\section{Authors' Biographies}

András Tilcsik is an assistant professor of strategic management at the Rotman School of Management, University of Toronto, 105 St. George Street, Toronto, ON M5S 3E6, Canada (e-mail: andras.tilcsik@rotman.utoronto.ca). His research explores the mutual influence between organizations and the individuals that constitute them. He received his Ph.D. in organizational behavior from Harvard University.

Michel Anteby is a visiting associate professor at the Yale School of Management and an associate professor at the Harvard Business School, Soldiers Field, Boston, MA 02163 (e-mail: manteby@hbs.edu). His research looks at how people relate to their work, their occupations, and the organizations they belong to. He received a joint Ph.D. in management from NYU and in sociology from EHESS (France).

Carly Knight is a Ph.D. candidate in the Department of Sociology at Harvard University, 33 Kirkland Street, Cambridge, MA 02138 (e-mail: crknight@fas.harvard.edu). Her research addresses questions regarding the state, labor markets, and inequality. Her dissertation investigates the historical origins of the metaphor of corporate personhood. 